Review

\title{
A review of chloride transport in alkali-activated cement paste, mortar, and concrete
}

8 Jorge Osio-Norgaard, Juan Pablo Gevaudan, Wil V. Srubar III*

Department of Civil, Environmental, and Architectural Engineering, University of Colorado Boulder, ECOT 441 UCB 428, Boulder, CO 80309-0428 USA

\section{H I G H L I G H T S}

- A review and statistical meta-analysis of chloride transport in AACs is presented.

- The role of $\mathrm{Ca}^{2+}$ in glassy/non-glassy phases within precursors is elucidated.

- Higher Si:Al, Na:Al, and heat-curing, in general, improve chloride resistance.

- Limitations of current chloride transport measurement techniques are addressed.

- Research needs concerning chloride durability of AACs are identified and discussed.

\section{A R T I C L E I N F O}

\section{Article history:}

Received 14 June 2018

Received in revised form 11 July 2018

Accepted 17 July 2018

Available online $\mathrm{xxxx}$

\section{Keywords:}

Alkali-activated cements

Porosity

Chloride transport

\begin{abstract}
A B S T R A C T
In this review, we present a meta-analysis of experimental data concerning chloride transport in alkaliactivated cement (AAC) paste, mortar, and concrete. Sixty-six (66) studies were reviewed with a primary focus on measurement methodology, mixture design, and process-structure-property relationships related to microstructural development (i.e., porosity, pore size distribution), chloride diffusion, and chloride binding. In general, this review elucidates that aluminosilicate precursors with high amorphous content and increased fineness and activating solutions with high alkalinities ( $\mathrm{Na}: \mathrm{Al} \geq 0.75)$ and silica contents $(\mathrm{Si}: \mathrm{Al} \geq 1.5)$ in combination with heat curing $\left(>40^{\circ} \mathrm{C}\right)$ lead to microstructural characteristics (e.g., binder gel chemistries) that improve chloride durability, even though interactions between these factors are not well understood. Descriptive statistics of reported AAC paste porosities and AAC concrete chloride diffusion coefficients by aluminosilicate precursor (i.e., fly ash, slag, calcined clay, natural clay, binary blends) are presented, along with a summative discussion regarding new opportunities for advancing current scientific understanding of chloride transport in AACs.
\end{abstract}

(C) 2018 Published by Elsevier Ltd.

\section{Contents}

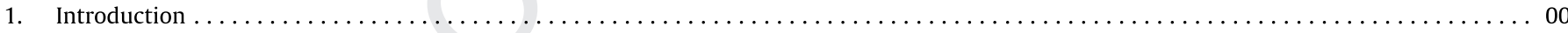

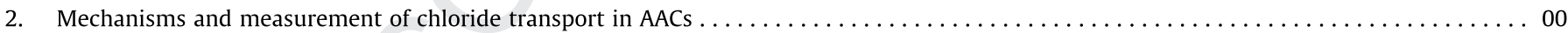

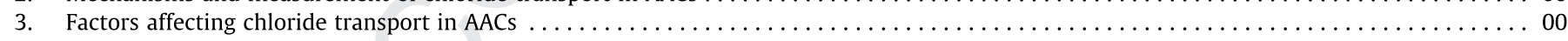

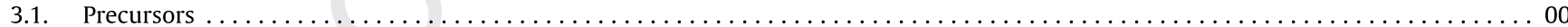

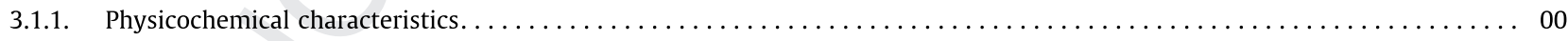

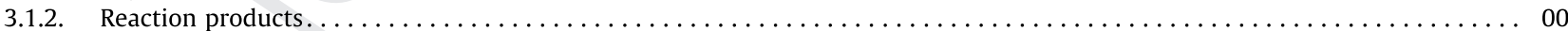

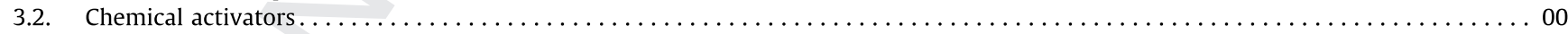

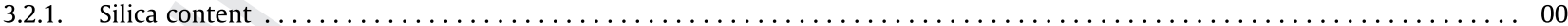

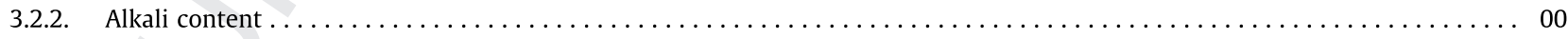

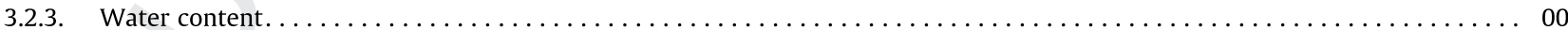

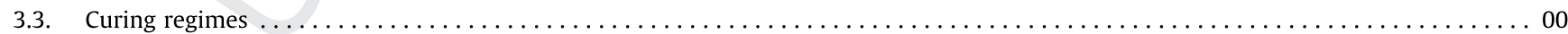

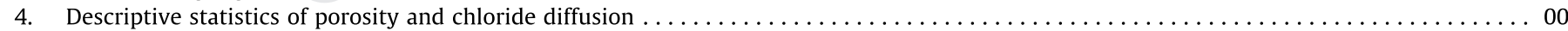

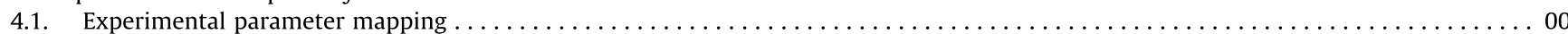

\footnotetext{
* Corresponding author.

E-mail address: wsrubar@colorado.edu (W.V. Srubar III).
} 
4.2. Porosity of AAC pastes by precursor

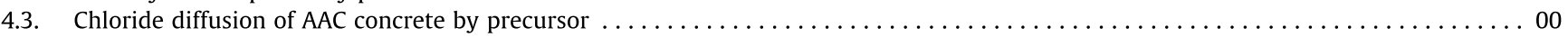

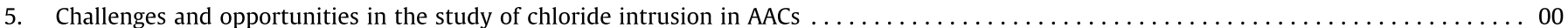

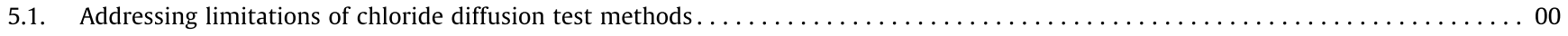

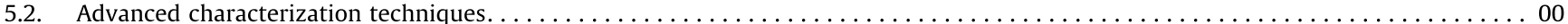

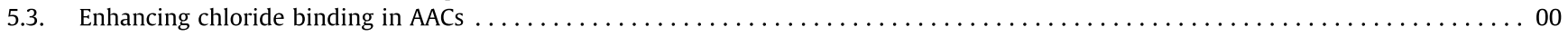

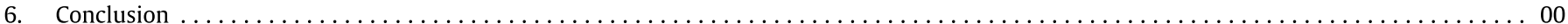

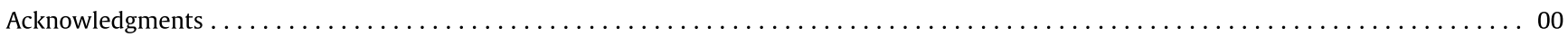

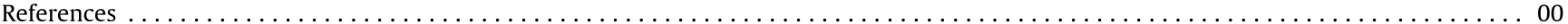

\section{Introduction}

Chloride-induced corrosion is a pervasive durability issue that continues to plague reinforced concrete structures worldwide. Approximately $3.4 \%$ of the global GDP ( $\$ 2.5$ Trillion USD) is spent each year to prevent, mitigate, and repair civil infrastructure damage due to chloride-induced corrosion [1]. Waterborne and airborne chlorides in marine environments and chlorides from surface-applied deicing salts exacerbate risks of chloride-induced depassivation and subsequent corrosion of mild steel in reinforced concrete structures. Fortuitously, the alkaline pore solution of ordinary portland cement (OPC) paste induces chemical passivation of mild steel at early ages by creating a thin, dense, self-protective layer of iron oxides and hydroxides [2]. However, transport of chloride ions through the cementitious matrix and its resulting accumulation at the steel surface can depassivate this protective layer. Chloride anions react with metal cations, creating corrosion products and liberating protons that result in a more local acidic environment, promoting further depassivation.

Alkali-activated cements (AACs) have emerged as a potential alternative to OPC in recent years because of comparable-and occasionally superior-mechanical and durability properties and potentially lower environmental impacts [3-5]. AACs are synthesized by dissolving an aluminosilicate material (e.g., fly ash, slag, metakaolin) in a highly alkaline solution, most often in the presence of soluble silicates [6]. Precursor dissolution enables gelation and subsequent formation of an inorganic aluminosilicate polymer comprised of silica and alumina tetrahedra linked in three dimensions $[4,7]$. For a comprehensive review of AACs and more detailed information regarding their synthesis, microstructure, and material properties, see $[3,4]$. Other helpful reviews concerning the durability of AAC materials include [5,8,9], and [10].

The objective of this work-and what distinguishes it from prior literature reviews-is to provide a comprehensive overview of the process-structure-property relationships of AACs as they pertain to chloride transport. Sixty-six (66) studies were reviewed with a primary focus on measurement methodology, mixture design, and process-structure-property relationships related to microstructural development (i.e., porosity, pore size distribution), chloride diffusion, and chloride binding. These studies were selected because they explicitly investigated how physical and chemical properties of aluminosilicate precursors, activator content, and/or and properties that affect chloride transport in AAC paste, mortar, and/or concrete. The content of this review is organized into the following main topics: (1) chloride transport mechanisms and characterization methods, (2) factors that influence microstructural development and material properties that affect chloride transport in AACs, (3) a meta-analysis of published experimental data, and (4) limitations of characterization methods for chloride intrusion in AAC paste, mortar, and concrete. We conclude this review by highlighting challenges, limitations, and future opportunities to advance scientific understanding of chloride transport in AACs. other processing parameters impact microstructural development
Chloride transport through porous cementitious materials is governed by three primary mechanisms: hydrostatic pressure, capillary absorption, and diffusion. Hydrostatic pressure drives chloride ions into the cement matrix by pressure gradients. If a hydraulic head of seawater is applied to a concrete surface, for example, chlorides will penetrate the surface [11]. In contrast, capillary absorption is driven by small intermolecular forces within the pores sized in the $10 \mathrm{~nm}-10 \mu \mathrm{m}$ range, enabling absorption of ionic liquids without assistance from external forces. Chloride ions also diffuse through cementitious media via concentration gradients. Provided that the concrete is sufficiently saturated (>80\%) [12], high concentrations of chloride ions will diffuse into the bulk through all interconnected pores where there is an initially lower concentration of chloride ions.

Hardened-state material properties, including porosity, pore solution chemistry, pore size distribution, tortuosity, and chloride binding potential, are well known to affect the rate of chloride transport in cementitious materials [11], and although their measurement has been standardized for OPC concrete, oftentimes all of them are not assessed in one study. Standard characterization methods for ion transport in AAC concrete, however, are much less established. While AAC-specific tests and protocols for chloride ion transport are still emerging (see Section 4), early attempts at understanding mechanisms that underlie/influence these effects have been adapted from tests developed for OPC concrete. Specifically, these tests (see Table 1) include direct and indirect physical tests (i.e., sorptivity, porosimetry, permeability, water absorption), chemical tests (i.e., chloride penetration), and electrical tests (i.e., resistivity). Indirect physical tests focus on microstructural characterization (i.e., pore size, total porosity) or utilize proxy measurements (i.e., water absorption, permeability) and relate these properties to durability. While indicative of microstructural characteristics, these physical tests cannot directly measure chloride diffusion or chloride resistance, but they are a useful way to estimate how AACs may perform in the presence of an ionic chloride solution. Chemical tests (e.g., chloride ponding) are often used to directly assess (1) time-dependent chloride penetration, (2) chloride content through the sample thickness using an indicator such as $\mathrm{AgNO}_{3}$, and (3) chloride binding using solubility techniques $[13,14]$. From these tests, a diffusion rate (i.e., diffusion coefficient) can be calculated. Lastly, resistivity methods are utilized to provide a quantitative measure chloride ion transport, where decreased resistivity indicates higher degrees of chloride penetration. As is further discussed in the context of our statistical analysis of reviewed literature in Section 4, each of these methodologies has inherent limitations in their measurement that must be understood so as to not obfuscate understanding of chloride intrusion in AACs.

\section{Factors affecting chloride transport in AACs}

In AAC concrete, chloride transport is influenced by (1) the type of precursor and its physical and chemical properties (i.e., 
Table 1

Summary aluminosilicate precursors ${ }^{1}$, activators, and characterization methods ${ }^{2}$ of properties that affect chloride transport in AAC paste, mortar, and concrete, as well as preconditioning regimes ${ }^{3}$ performed prior to their measurement.

\begin{tabular}{|c|c|c|c|c|c|c|c|c|}
\hline Author(s) & Year & Precursor(s) & Activator(s) & Pore Structure & Chloride Diffusion & $\begin{array}{l}\text { Chloride } \\
\text { Binding }\end{array}$ & $\begin{array}{l}\text { Preconditioning } \\
\text { Regime(s) }\end{array}$ & Reference \\
\hline \multicolumn{9}{|l|}{ AAC Paste } \\
\hline Bakharev et al. & 2005 & FA & $\mathrm{NaOH}+\mathrm{NaSi}+\mathrm{KOH}$ & BET & N/A & N/A & $\mathrm{N} / \mathrm{A}$ & [15] \\
\hline $\begin{array}{l}\text { Kovalchuck } \\
\text { et al. }\end{array}$ & 2006 & FA & $\mathrm{NaOH}+\mathrm{NaSi}$ & MIP & $\mathrm{N} / \mathrm{A}$ & $\mathrm{N} / \mathrm{A}$ & OD $\left(105^{\circ} \mathrm{C}\right)$ & [16] \\
\hline Skavara et al. & 2009 & FA & $\mathrm{NaOH}+\mathrm{NaSi}$ & MIP & $\mathrm{N} / \mathrm{A}$ & $\mathrm{N} / \mathrm{A}$ & N/A & [17] \\
\hline $\begin{array}{l}\text { Winnefeld } \\
\text { et al. }\end{array}$ & 2010 & FA & $\mathrm{NaOH}+\mathrm{NaSi}$ & $\mathrm{SEM}^{\dagger}$ & $\mathrm{N} / \mathrm{A}$ & $\mathrm{N} / \mathrm{A}$ & N/A & [18] \\
\hline Ma et al. & 2013 & FA & $\mathrm{NaOH}+\mathrm{NaSi}$ & MIP & N/A & $\mathrm{N} / \mathrm{A}$ & Vacuum Freeze Dry & [19] \\
\hline Hlavacek et al. & 2014 & FA & $\mathrm{NaOH}+\mathrm{NaSi}$ & $\begin{array}{l}\text { Paste Bulk } \\
\text { Density }\end{array}$ & $\mathrm{N} / \mathrm{A}$ & $\mathrm{N} / \mathrm{A}$ & $\mathrm{N} / \mathrm{A}$ & [20] \\
\hline Roy et al. & 2000 & $\mathrm{~S}$ & $\begin{array}{l}\mathrm{NaOH}+\mathrm{KOH}+ \\
\mathrm{Na}_{2} \mathrm{SO}_{4}+\mathrm{Na}_{2} \mathrm{CO}_{3}\end{array}$ & MIP & In house diffusivity & $\mathrm{N} / \mathrm{A}$ & N/A & [21] \\
\hline Collins et al. & 2000 & $\mathrm{~S}$ & $\mathrm{NaSi}+$ Lime & MIP & N/A & $\mathrm{N} / \mathrm{A}$ & N/A & [22] \\
\hline Melo et al. & 2008 & $S$ & $\mathrm{NaSi}$ & MIP & $\mathrm{N} / \mathrm{A}$ & N/A & ASTM D4404 & [23] \\
\hline Ben Haha et al. & 2011 & $S$ & $\mathrm{NaOH}+\mathrm{NaSi}$ & $\mathrm{SEM}^{\dagger}$ & $\mathrm{N} / \mathrm{A}$ & $\mathrm{N} / \mathrm{A}$ & $\mathrm{N} / \mathrm{A}$ & [24] \\
\hline Ben Haha et al. & 2011 & $S$ & $\mathrm{NaOH}+\mathrm{NaSi}$ & $\mathrm{SEM}^{\dagger}$ & $\mathrm{N} / \mathrm{A}$ & $\mathrm{N} / \mathrm{A}$ & $\mathrm{N} / \mathrm{A}$ & [25] \\
\hline Puertas et al. & 2011 & $\mathrm{~S}$ & $\mathrm{NaOH}+\mathrm{NaSi}$ & $\mathrm{N} / \mathrm{A}$ & N/A & $\mathrm{N} / \mathrm{A}$ & N/A & [26] \\
\hline Ye et al. & 2017 & $\mathrm{~S}$ & $\mathrm{NaOH}+\mathrm{NaSi}$ & MIP & $\mathrm{N} / \mathrm{A}$ & $\mathrm{N} / \mathrm{A}$ & $\begin{array}{l}\text { Vacuum Dry }\left(50^{\circ} \mathrm{C}\right)+ \\
\text { OD }\left(105^{\circ} \mathrm{C}\right)\end{array}$ & [27] \\
\hline Ortega, et al. & 2000 & UC & $\mathrm{Ca}(\mathrm{OH})_{2}$ & $\begin{array}{l}\text { Water } \\
\text { Absorption }\end{array}$ & $\mathrm{N} / \mathrm{A}$ & $\mathrm{N} / \mathrm{A}$ & $\mathrm{OD}\left(105^{\circ} \mathrm{C}\right)$ & {$[28]$} \\
\hline Duxson et al. & 2005 & MK & $\mathrm{NaOH}+\mathrm{SiO}$ & BET & N/A & $\mathrm{N} / \mathrm{A}$ & $100^{\circ} \mathrm{C}$ & [29] \\
\hline $\begin{array}{l}\text { Gevaudan } \\
\text { et al. }\end{array}$ & 2017 & MK & $\mathrm{NaOH}+\mathrm{NaSi}$ & Modified A & $\mathrm{N} / \mathrm{A}$ & $\mathrm{N} / \mathrm{A}$ & $\begin{array}{l}\text { Solvent exchange, OD } \\
\left({ }^{\circ} \mathrm{C}\right)\end{array}$ & [30] \\
\hline Pan et al. & 2003 & $\begin{array}{l}\text { Binary (S + Red } \\
\text { Mud) }\end{array}$ & $\begin{array}{l}\mathrm{NaSi}+\text { Sodium } \\
\text { Aluminate }\end{array}$ & MIP & Ponding & N/A & N/A & [31] \\
\hline Lloyd et al. & 2010 & $\begin{array}{l}\text { Binary }(F A+S) \\
F A\end{array}$ & $\mathrm{NaOH}+\mathrm{KOH}+\mathrm{NaSi}$ & $\begin{array}{l}\text { Water } \\
\text { Absorption }\end{array}$ & In house diffusivity & $\mathrm{N} / \mathrm{A}$ & $\mathrm{N} / \mathrm{A}$ & [32] \\
\hline Zhang et al. & 2010 & $\begin{array}{l}\text { Binary }(\mathrm{FA}+\mathrm{MK}) \text {, } \\
\text { FA }\end{array}$ & $\mathrm{NaOH}+\mathrm{NaSi}$ & MIP + BET & N/A & $\mathrm{N} / \mathrm{A}$ & $\begin{array}{l}\text { Solvent Exchange, OD } \\
\left({ }^{\circ} \mathrm{C}\right)\end{array}$ & [33] \\
\hline Provis et al. & 2012 & $\begin{array}{l}\text { Binary }(F A+S) \text {, } \\
\text { FA }\end{array}$ & $\mathrm{NaSi}$ & $\mu \mathrm{CT}$ & N/A & $\mathrm{N} / \mathrm{A}$ & $\mathrm{N} / \mathrm{A}$ & [34] \\
\hline Zhu et al. & 2014 & Binary $(S+F A)$ & $\mathrm{NaOH}+\mathrm{NaSi}$ & $\begin{array}{l}\text { MIP, Water } \\
\text { Absorption }\end{array}$ & Ponding & $\mathrm{N} / \mathrm{A}$ & $\mathrm{OD}\left(65^{\circ} \mathrm{C}\right)$ & [35] \\
\hline Ismail et al. & 2014 & Binary $(S+F A)$ & $\mathrm{NaSi}$ & $\mathrm{SEM}^{\dagger}$ & $\mathrm{N} / \mathrm{A}$ & N/A & $\mathrm{N} / \mathrm{A}$ & [36] \\
\hline Yang et al. & 2014 & Binary $(S+F A)$ & $\mathrm{NaOH}+\mathrm{NaSi}$ & $\begin{array}{l}\text { MIP, Water } \\
\text { Absorption }\end{array}$ & $\begin{array}{l}\text { Short Term Salt } \\
\text { Ponding }\end{array}$ & $\mathrm{N} / \mathrm{A}$ & $\mathrm{OD}\left(105^{\circ} \mathrm{C}\right)$ & [37] \\
\hline Lee et al. & 2016 & Binary $(S+F A)$ & $\mathrm{NaOH}+\mathrm{NaSi}$ & $\mathrm{B}, \mathrm{C}$ & $\mathrm{D}, \mathrm{E}$ & $\begin{array}{l}\text { Acid-soluble } \\
\text { chlorides }\end{array}$ & N/A & [13] \\
\hline Yao et al. & 2016 & Binary $(S+F A)$ & $\mathrm{NaOH}+\mathrm{NaSi}$ & MIP & $\mathrm{N} / \mathrm{A}$ & N/A & $\begin{array}{l}\text { Solvent Exchange + OD } \\
\left(60^{\circ} \mathrm{C}\right)\end{array}$ & [38] \\
\hline $\begin{array}{l}\text { Noor-ul-amin } \\
\text { et al. }\end{array}$ & 2017 & $\begin{array}{l}\text { Binary (Bagasse } \\
\text { ash + UC) }\end{array}$ & $\mathrm{NaSi}$ & N/A & Ponding & $\mathrm{N} / \mathrm{A}$ & $\mathrm{N} / \mathrm{A}$ & [39] \\
\hline Long et al. & 2017 & Binary $(S+F A)$ & $\mathrm{NaSi}$ & $\mu \mathrm{CT}$ & $\mathrm{N} / \mathrm{A}$ & $\mathrm{N} / \mathrm{A}$ & $\mathrm{N} / \mathrm{A}$ & [40] \\
\hline Ren et al. & 2017 & Binary, Ternary & $\mathrm{NaOH}+\mathrm{NaSi}$ & MIP & Ponding & $\mathrm{N} / \mathrm{A}$ & $\mathrm{OD}\left(105^{\circ} \mathrm{C}\right)$ & [41] \\
\hline \multicolumn{9}{|l|}{$A A C$ Mortar } \\
\hline Miranda et al. & 2005 & FA & $\mathrm{NaOH}+\mathrm{NaSi}$ & $\mathrm{SEM}^{\dagger}$ & N/A & $\mathrm{N} / \mathrm{A}$ & $\mathrm{N} / \mathrm{A}$ & [42] \\
\hline criado et al. & 2011 & FA & $\mathrm{NaOH}+\mathrm{NaSi}$ & MIP & $\mathrm{N} / \mathrm{A}$ & N/A & N/A & [43] \\
\hline $\begin{array}{l}\text { Asprogerakas } \\
\text { et al. }\end{array}$ & 2014 & FA & $\mathrm{NaOH}+\mathrm{NaSi}$ & $\mathrm{N} / \mathrm{A}$ & NT Build 443 & $\mathrm{~N} / \mathrm{A}$ & $\mathrm{N} / \mathrm{A}$ & [44] \\
\hline $\begin{array}{l}\text { Monticelli } \\
\text { et al. }\end{array}$ & 2016 & FA & $\mathrm{NaOH}+\mathrm{NaSi}$ & MIP & $\mathrm{F}$ & D & $\mathrm{N} / \mathrm{A}$ & {$[14]$} \\
\hline $\begin{array}{l}\text { Monticelli } \\
\text { et al. }\end{array}$ & 2016 & FA & $\mathrm{NaOH}+\mathrm{NaSi}$ & MIP, EN1015 & Ponding & $\mathrm{N} / \mathrm{A}$ & N/A & [45] \\
\hline Shi et al. & 1996 & $S$ & $\begin{array}{l}\mathrm{NaOH}+\mathrm{Na}_{2} \mathrm{CO}_{3}+ \\
\mathrm{NaSi}\end{array}$ & MIP & A & $\mathrm{N} / \mathrm{A}$ & $\mathrm{N} / \mathrm{A}$ & [46] \\
\hline Brough et al. & 2002 & $S$ & $\mathrm{NaSi}$ & $\mathrm{SEM}^{\dagger}$ & $\mathrm{N} / \mathrm{A}$ & $\mathrm{N} / \mathrm{A}$ & N/A & [47] \\
\hline Zuda et al & 2007 & $\mathrm{~S}$ & $\mathrm{NaSi}$ & $\begin{array}{l}\text { Water } \\
\text { Absorption }\end{array}$ & Bulk Diffusivity & $\mathrm{N} / \mathrm{A}$ & N/A & [48] \\
\hline Aydin et al. & 2012 & S & $\mathrm{NaOH}+\mathrm{NaSi}$ & $\mathrm{N} / \mathrm{A}$ & N/A & $\mathrm{N} / \mathrm{A}$ & N/A & [49] \\
\hline Palomo et al. & 1999 & MK & $\mathrm{NaOH}+\mathrm{NaSi}$ & $\begin{array}{l}\text { Water } \\
\text { Absorption }\end{array}$ & N/A & $\mathrm{N} / \mathrm{A}$ & N/A & [50] \\
\hline Chi et al. & 2013 & Binary $(S+F A), S$ & $\mathrm{NaOH}+\mathrm{NaSi}$ & B & $\mathrm{N} / \mathrm{A}$ & N/A & $\mathrm{N} / \mathrm{A}$ & [51] \\
\hline Ismail et al. & 2013 & Binary $(S+F A), S$ & $\mathrm{NaSi}$ & B & $\mathrm{E}, \mathrm{G}$ & $\mathrm{D}$ & $\mathrm{OD}\left(60^{\circ} \mathrm{C}\right)$ & [52] \\
\hline Zhu et al. & 2014 & Binary $(S+F A), S$ & $\mathrm{NaOH}+\mathrm{NaSi}$ & $\begin{array}{l}\text { MIP, Water } \\
\text { Absorption }\end{array}$ & Ponding & $\mathrm{N} / \mathrm{A}$ & $\mathrm{OD}\left(65^{\circ} \mathrm{C}\right)$ & [35] \\
\hline Karim et al. & 2017 & Ternary & $\mathrm{NaOH}$ & B, BS EN196 & JIS A6203 & $\mathrm{N} / \mathrm{A}$ & N/A & [53] \\
\hline $\begin{array}{l}\text { AAC Concrete } \\
\text { Arham et al. }\end{array}$ & 2009 & FA & $\mathrm{NaOH}+\mathrm{NaSi}$ & $\mathrm{C}$ & $\begin{array}{l}\text { A, G, AASHTO T } \\
259\end{array}$ & $\mathrm{~N} / \mathrm{A}$ & OD $\left(105^{\circ} \mathrm{C}\right)$ & [54] \\
\hline
\end{tabular}


Table 1 (continued)

\begin{tabular}{|c|c|c|c|c|c|c|c|c|}
\hline Author(s) & Year & Precursor(s) & Activator(s) & Pore Structure & Chloride Diffusion & $\begin{array}{l}\text { Chloride } \\
\text { Binding }\end{array}$ & $\begin{array}{l}\text { Preconditioning } \\
\text { Regime(s) }\end{array}$ & Reference \\
\hline $\begin{array}{l}\text { Kupwade-patil } \\
\text { et al. }\end{array}$ & 2013 & FA & $\mathrm{NaOH}+\mathrm{NaSi}$ & MIP & A, D & $\mathrm{N} / \mathrm{A}$ & $\mathrm{N} / \mathrm{A}$ & {$[55]$} \\
\hline $\begin{array}{l}\text { Chindraprasirt } \\
\text { et al. }\end{array}$ & 2014 & FA & $\mathrm{NaOH}+\mathrm{NaSi}$ & $\mathrm{N} / \mathrm{A}$ & $\mathrm{D}, \mathrm{E}$ & $\mathrm{N} / \mathrm{A}$ & $\mathrm{N} / \mathrm{A}$ & {$[56]$} \\
\hline Law et al. & 2014 & FA & $\mathrm{NaOH}+\mathrm{NaSi}$ & $\mathrm{N} / \mathrm{A}$ & $\begin{array}{l}\text { A, AASHTO T259 \& } \\
\text { T277 }\end{array}$ & $\mathrm{N} / \mathrm{A}$ & $\mathrm{N} / \mathrm{A}$ & [57] \\
\hline $\begin{array}{l}\text { Gunasekara } \\
\text { et al. }\end{array}$ & 2016 & FA & $\mathrm{NaOH}+\mathrm{NaSi}$ & $\begin{array}{l}\text { AS10112.21, } \\
\text { MIP }\end{array}$ & AASHTO T259 & $\mathrm{N} / \mathrm{A}$ & OD $\left(105^{\circ} \mathrm{C}\right)$ & [58] \\
\hline Nuaklong et al. & 2016 & FA & $\mathrm{NaOH}+\mathrm{NaSi}$ & B & $\begin{array}{l}\text { Chloride } \\
\text { Penetration Depth }\end{array}$ & $\mathrm{N} / \mathrm{A}$ & $\mathrm{N} / \mathrm{A}$ & [59] \\
\hline $\begin{array}{l}\text { Gunasekara } \\
\text { et al. }\end{array}$ & 2017 & FA & $\mathrm{NaOH}+\mathrm{NaSi}$ & $\mathrm{N} / \mathrm{A}$ & $\mathrm{N} / \mathrm{A}$ & $\mathrm{N} / \mathrm{A}$ & $\mathrm{N} / \mathrm{A}$ & {$[60]$} \\
\hline Al-Otaibi & 2009 & $\mathrm{~S}$ & $\mathrm{NaSi}$ & RILEM CPC-11.3 & A, ASSHTO T277 & $\mathrm{N} / \mathrm{A}$ & $\mathrm{N} / \mathrm{A}$ & [61] \\
\hline Lim et al. & 2012 & $\mathrm{~S}$ & $\mathrm{NaOH}$ & $\mathrm{N} / \mathrm{A}$ & Ponding Test & $\mathrm{N} / \mathrm{A}$ & $\mathrm{N} / \mathrm{A}$ & [62] \\
\hline Chi et al. & 2012 & $\mathrm{~S}$ & $\mathrm{NaOH}+\mathrm{NaSi}$ & $\mathrm{N} / \mathrm{A}$ & A & $\mathrm{N} / \mathrm{A}$ & $\mathrm{N} / \mathrm{A}$ & [63] \\
\hline Law et al. & 2012 & $\mathrm{~S}$ & $\mathrm{NaOH}+\mathrm{NaSi}$ & $\mathrm{N} / \mathrm{A}$ & A, AASHTO T277 & $\mathrm{N} / \mathrm{A}$ & $\mathrm{N} / \mathrm{A}$ & [64] \\
\hline $\begin{array}{l}\text { Ravikumar } \\
\text { et al. }\end{array}$ & 2013 & $\mathrm{~S}$ & $\mathrm{NaOH}+\mathrm{NaSi}$ & MIP & A, NT Build 492 & $\mathrm{~N} / \mathrm{A}$ & $\mathrm{N} / \mathrm{A}$ & [65] \\
\hline Ma et al. & 2015 & $\mathrm{~S}$ & $\mathrm{NaOH}+\mathrm{NaSi}$ & $\mathrm{N} / \mathrm{A}$ & $\begin{array}{l}\text { NT Build 442, NT } \\
\text { Build } 492\end{array}$ & $\mathrm{~N} / \mathrm{A}$ & $\mathrm{N} / \mathrm{A}$ & {$[66]$} \\
\hline Balcikanli et al. & 2016 & $S$ & $\mathrm{NaOH}+\mathrm{NaSi}$ & $\mathrm{N} / \mathrm{A}$ & A & $\mathrm{N} / \mathrm{A}$ & N/A & [67] \\
\hline Parthiban et al. & 2017 & $\mathrm{~S}$ & $\mathrm{NaOH}+\mathrm{NaSi}$ & B & $\begin{array}{l}\text { AASHTO T259 \& } \\
\text { T260 }\end{array}$ & $\mathrm{N} / \mathrm{A}$ & $\mathrm{N} / \mathrm{A}$ & [68] \\
\hline Behfarnia et al. & 2017 & $\mathrm{~S}$ & $\mathrm{NaOH}+\mathrm{NaSi}$ & $\begin{array}{l}\text { B, BS 1881: } \\
\text { part122 }\end{array}$ & A, G & $\mathrm{N} / \mathrm{A}$ & $\mathrm{N} / \mathrm{A}$ & [69] \\
\hline Bondar et al. & 2012 & $\mathrm{CC}, \mathrm{UC}$ & $\mathrm{KOH}+\mathrm{NaSi}$ & $\mathrm{N} / \mathrm{A}$ & $\mathrm{A}, \mathrm{F}$ & $\mathrm{N} / \mathrm{A}$ & $\mathrm{N} / \mathrm{A}$ & [70] \\
\hline Bernal et al. & 2012 & Binary $(S+M K), S$ & $\mathrm{NaOH}+\mathrm{NaSi}$ & B & $\begin{array}{l}\text { A, In-house } \\
\text { diffusivity }\end{array}$ & $\mathrm{N} / \mathrm{A}$ & $\mathrm{OD}\left(100^{\circ} \mathrm{C}\right)$ & [71] \\
\hline Ismail et al. & 2013 & Binary $(S+F A), S$ & $\mathrm{NaSi}$ & B & $\begin{array}{l}\text { E, D, G, NT Build } \\
492\end{array}$ & $\mathrm{~N} / \mathrm{A}$ & $\mathrm{OD}\left(100^{\circ} \mathrm{C}\right)$ & [52] \\
\hline Bernal et al. & 2015 & Binary $(S+M K), S$ & $\mathrm{NaOH}+\mathrm{NaSi}$ & B & $\mathrm{N} / \mathrm{A}$ & $\mathrm{N} / \mathrm{A}$ & $\mathrm{N} / \mathrm{A}$ & [72] \\
\hline Albitar et al. & 2017 & $\begin{array}{l}\text { Binary }(S+F A) \\
\text { FA }\end{array}$ & $\mathrm{NaOH}+\mathrm{NaSi}$ & B & Ponding Test & $\mathrm{N} / \mathrm{A}$ & $\mathrm{OD}\left(110^{\circ} \mathrm{C}\right)$ & [73] \\
\hline $\begin{array}{l}\text { Tennakoon } \\
\text { et al. }\end{array}$ & 2017 & Binary $(S+F A)$ & $\mathrm{NaSi}$ & $\mathrm{N} / \mathrm{A}$ & A, NT Build 443 & $\mathrm{~N} / \mathrm{A}$ & $\mathrm{N} / \mathrm{A}$ & [74] \\
\hline Babaee et al. & 2016 & Ternary & $\mathrm{NaOH}+\mathrm{NaSi}$ & $\mathrm{N} / \mathrm{A}$ & Ponding Test & $\mathrm{N} / \mathrm{A}$ & $\mathrm{N} / \mathrm{A}$ & [75] \\
\hline Noushini et al. & 2016 & Ternary & $\mathrm{NaOH}+\mathrm{NaSi}$ & B & AASHTO TP-95 & $\mathrm{N} / \mathrm{A}$ & $\mathrm{OD}\left(100^{\circ} \mathrm{C}\right)$ & [76] \\
\hline
\end{tabular}

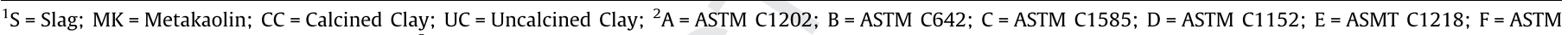

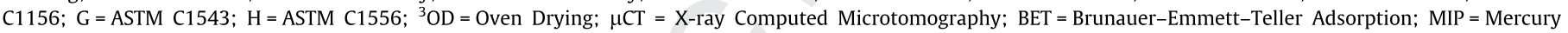
Intrusion Porosimetry; SEM = Scanning Electron Microscopy ${ }^{\dagger}=$ qualitative description of porosity.

crystallinity, fineness, chemical composition), (2) the chemistry of the alkali activating solution, and (3) curing regime [56]. The effect of these factors on properties that affect chloride transport is discussed in more detail in the following sections.

\subsection{Precursors}

The aim of this section is to briefly review AAC precursors utilized in the surveyed literature, address their variable chemical composition, and discuss how their physicochemical properties and reaction products influence chloride transport. The most common AAC precursors include (1) fly ash (FA), (2) ground granulated blast furnace slag (slag), and both (3) calcined (e.g., metakaolin) and (4) uncalcined aluminosilicate clays (e.g., kaolinite). The average chemical composition of each AAC precursor, based on the values reported in surveyed literature, is shown in Fig. 1. The data were obtained by aggregating published precursor oxide analysis data from 66 studies concerning chloride transport in AAC pastes, mortars, and concrete. This compositional data will be used to explain some of the variability in bulk properties observed in the literature.

\subsubsection{Physicochemical characteristics}

In AACs, chloride transport is affected by the physicochemical properties of aluminosilicate precursors. More specifically, physical properties, such as crystallinity and fineness, limit the degree of reactivity. Increasing precursor fineness and lowering degrees of crystallinity accelerate the dissolution of the precursor, which leads to denser pore networks and improved chloride resistance [77]. Increased particle fineness in FA, for example, has been shown to increase compressive strength of resulting AACs [38], which, in many AAC systems, has been linked to reduced porosity $[38,78]$.

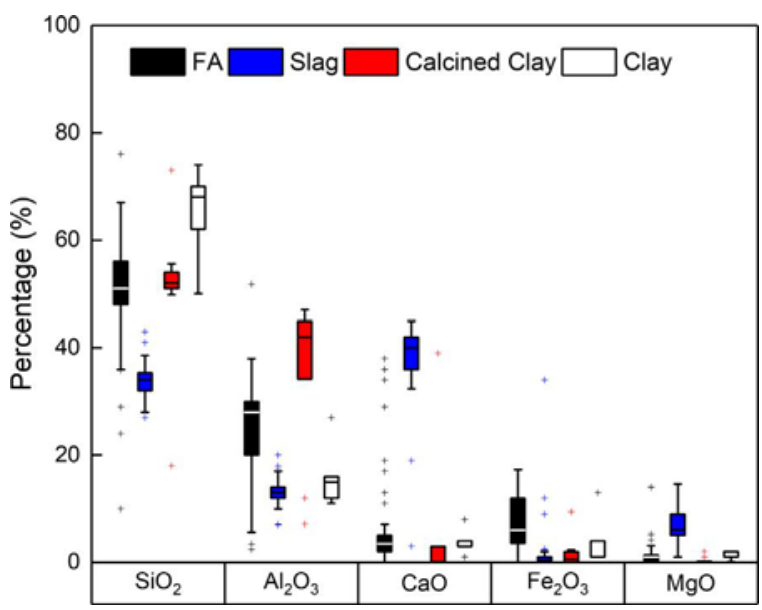

Fig. 1. Average chemical composition of all aluminosilicate AAC precursors reported by the studies included in this review. Median data are represented by centerlines in the box plots. 
208 However, in slag-based AACs, increased fineness often necessitates 209 higher water demand, which, when coupled with higher reactivity 210 due to a greater surface area, results in excess hydration water, 211 which has been noted by some researchers to yield higher porosi212 ties and lower strengths [4]. Like single precursor systems, particle 213 fineness affects the reactivity of blended systems in similar ways 214 [53]. When studying transport in any of these single or binary pre215 cursor systems it is important to assess how the properties of each 216 precursor will affect the binder structure and, therefore, its bulk 217 material properties.

3.1.1.1. Fly ash. $\mathrm{FA}$ is primarily composed of silicon dioxide $\left(\mathrm{SiO}_{2}\right)$, aluminum oxide $\left(\mathrm{Al}_{2} \mathrm{O}_{3}\right)$, iron oxide $\left(\mathrm{Fe}_{2} \mathrm{O}_{3}\right)$, and varied amounts of calcium oxide $(\mathrm{CaO})$. These oxides are contained in four major crystalline mineral phases: quartz, mullite, hematite, and magnetite, which can form $10-50 \%$ of the bulk ash, while the reminder is largely comprised of amorphous silicate glass $[77,79,80]$. FA is classified according to its chemical composition into two major categories - Class F and Class C - as specified by ASTM C618. These classifications depend on the chemical composition and do not address crystallinity. Historically, while the class definition has varied [81,82], current classification focuses on the combined content of silica, alumina, and iron oxides. To be considered Class F, FA is required to possess a minimum of $70 \%$ by weight of the aforementioned oxides, while a Class C FA requires a minimum of $50 \%$. However, this classification takes into account neither the crystalline content of the ash nor the compositional variation of its glassy phases [77]. Average oxide compositions of FAs used as AAC precursors in the literature reviewed herein are shown in Fig. 1. As anticipated, information regarding the crystallinity of FA is unavailable, given that only seven studies report FA crystallinity $[14,43-45,58,60,79]$. However, recent studies have identified crystallinity as an important processing parameter for AACs, and many have begun to report it and, in some cases, investigate it explicitly. For example, Sweeney et al. conducted durability experiments that focused primarily on the amorphous content of $\mathrm{SiO}_{2}$ and $\mathrm{Al}_{2} \mathrm{O}_{3}$ in $\mathrm{FA}$ [83].

While the majority of published FA studies reviewed herein focus on low-calcium FA (LCFA), a few studies have begun to investigate high-calcium FA (HCFA), because it is now commonly believed-despite experimental evidence to the contrary-that higher calcium contents lead to improved chloride durability. In Fig. $1 \mathrm{CaO}$ outliers correspond to studies that purposefully investigated HCFA [18,32,55,59]. HCFAs typically contain lower alumina contents and several calcium-containing crystalline phases (e.g., Larnite) [18,32]. Generally, in the studies reviewed herein, HCFA AACs exhibited higher porosities and lower chloride resistance than their LCFA counter parts $[18,32,55,59,84-86]$. Currently the poor performance of HCFA compared to LCFA AACs in terms of chloride durability remains unexplained. These finding are of note, because, generally, slag and OPC precursors with high calcium contents demonstrate a higher resistance to chloride intrusion [87], suggesting that the mineralogical phase of calcium (i.e., crystalline vs. amorphous) is perhaps more important than the total amount in each precursor.

3.1.1.2. Ground-granulated blast furnace slag. Ground granulated blast furnace slag, henceforth referred to as slag, is a highly vitreous, highly reactive, low-chemical-variability byproduct of the steel-making industry and, as asserted by Law et al., the most common material utilized in AAC production [64]. Primarily composed of glassy phases of $\mathrm{CaO}, \mathrm{SiO}_{2}, \mathrm{Al}_{2} \mathrm{O}_{3}, \mathrm{MgO}$, and $\mathrm{Fe}_{2} \mathrm{O}_{3}$, slags usually contain high $\mathrm{CaO}(30-50 \%)$, but not as high as OPC (>50\%) [46,64]. Although slags have low chemical variability, major differences between slags lie in their quantities of MgO, as shown in Fig. 1. Additionally, out of all precursors, slags consistently contain the lowest quantities of both $\mathrm{SiO}_{2}$ and $\mathrm{Al}_{2} \mathrm{O}_{3}$. Slag's glassy nature (>90\%) imparts increased reactivity compared to FA, and early stage studies of synthetic slags identify a rapid release of glassy $\mathrm{Ca}^{2+}$ upon dissolution $[88,89]$.

Slags for use in cement and concrete are currently classified according to ASTM C989 by their performance in a slag reactivity test, where 50/50 mixtures of slag and OPC are graded against an OPC control in terms of its compressive strength. Three reactivity grades of slag are reported: Grade 80, Grade 100, and Grade 120 , which indicates slag's potential performance as a supplementary cementitious material (SCM) but is not indicative of its suitability as an AAC precursor. While more applicable classification schemes for slag and other AAC precursors remain to be developed, the current mission of RILEM TC 238-SCM is to define best practices for characterizing the reactivity of SCMs, including slag [90], which will likely also yield better proxy classifications for slag (and other) AAC precursors.

3.1.1.3. Uncalcined and calcined aluminosilicate clays. Naturally occurring, crystalline aluminosilicate clays can be utilized to produce AAC binders either in their raw or calcined form. A variety of natural clays can be subjected to calcination and subsequently used for alkali activation. Natural clays, like kaolinite, contain varying amounts of $\mathrm{SiO}_{2}$ and $\mathrm{Al}_{2} \mathrm{O}_{3}$ and can be calcined (i.e., heated to temperatures of $400-1000{ }^{\circ} \mathrm{C}$ ) to achieve dehydroxylation, which induces crystalline-to-amorphous structural changes and, consequently, increases reactivity $[91,92]$. In general, increased calcination temperature lowers the degree of crystallinity of these clays. In the few studies reviewed herein, metakaolin was the most commonly utilized calcined clay to produce AACs that were subject to chloride durability tests. As a distinctly pure aluminosilicate, metakaolin precursors are high in $\mathrm{SiO}_{2}$ and $\mathrm{Al}_{2} \mathrm{O}_{3}$, as evidenced by the calcined clay versus natural clay data shown in Fig. 1. Bumamis et al. showed that the amounts of reactive silica and alumina in clay precursors were related to improved physical properties of the cement paste, such as density, water absorption, and porosity [93]. However, no definitive conclusion should be drawn about the average chemical composition of all calcined clays used in alkali activation, given the limited number of published AAC studies concerning calcined clays and chloride transport $[41,85,87,94,95]$ (see Table 1$)$.

3.1.1.4. Blended systems. Numerous types of blended precursor systems have been utilized in AAC systems, and those that have been used to study chloride-related performance are included within the scope of this review. Blended systems range from FA/slag and slag/metakaolin binary systems to a variety of other binary and ternary systems that involve rice husk ash or red mud $[4,91,96]$. Despite these studies, much research is still needed to understand the physical properties and chemistries of combined precursors in blended systems and their impact on microstructural development and resulting material properties [96], especially as they pertain to properties that influence chloride transport. With a burgeoning understanding of heterogenous single precursor systems, it remains a scientific challenge to fully understand and predict structure-property relationships imparted by precursor blends.

A greater understanding of the role of the various glass and crystalline phases in blended precursors need be acquired. Out of the 24 reviewed studies addressing chloride diffusion and binding in binary precursor systems, only five studies attempted to characterize the crystallinity of the mixed precursors, and none discuss the complex dissolution kinetics of the different glass phases of each precursor in the system. As previously discussed, in general, blended slag-containing precursors with high calcium contents have exhibited greater chloride resistance. However, other nonslag high-calcium-containing precursor blends do not perform as 
well as low-calcium blends in terms chloride penetration than OPC controls [84,97], further substantiating that vitreous calcium phases are preferred to their crystalline counterparts.

\subsubsection{Reaction products}

The activation of aluminosilicate precursors leads to the creation of a variety of reaction products that depend on precursor chemistry and curing regime. Some of the reaction products observed are binder gels (e.g., C-S-H, C-A-S-H, N-A-S-H), and various authors additionally report finding crystalline phases, including hydrotalcite, zeolites, and other unreacted minerals.

In general $\mathrm{C}-\mathrm{A}-\mathrm{S}-\mathrm{H}$ and $\mathrm{N}-\mathrm{A}-\mathrm{S}-\mathrm{H}$, the two main binder gels produced in alkali activation, create distinct microstructural characteristics (e.g., pores) that, in turn, affect chloride transport. In $\mathrm{N}-\mathrm{A}-\mathrm{S}-\mathrm{H}$ binders, large macropores are often accompanied by small gel pores that exist within the gel, whereas a more continuous distribution of pore sizes are found in C-A-S-H gels similar to OPC binders. Lloyd et al. and Ma et al. show low-calcium FAbased AACs consist of homogenous $\mathrm{N}-\mathrm{A}-\mathrm{S}-\mathrm{H}$ gels occupying much of the sample structure with pores much larger than capillary pores found in OPC $[19,98]$. Although important for diffusion, gel pores are difficult to investigate due to their small radius and current limitations of porosimetry equipment $[17,98]$. N-A-S-H binder gels continue densifying the cement matrix due to a process of continued gelation, which reduces pore space over time, temporally affecting chloride diffusivity [58]. Although continued gelation of $\mathrm{N}-\mathrm{A}-\mathrm{S}-\mathrm{H}$ binder gels is beneficial, excessive gelation causes depletion of pore solution, which can accelerate steel corrosion in these systems [60]. Leaching of alkalis from the pore solution due to aqueous exposure can inhibit further gelation in N-A-S$\mathrm{H}$ systems as they age [38]. This combination of natural leaching and continued gelation could hamper the long-term durability of $\mathrm{N}-\mathrm{A}-\mathrm{S}-\mathrm{H}$ based cements. C-A-S-H and C-S-H gels have significant amounts of bound water, which may reduce the porosity of the system and explain lower water absorption [51]. However, Winnefeld et al. postulated that low-calcium FA-based AACs that produce N-A-S-H gel exhibit lower porosities than high-calcium samples because more binder gel (i.e., C-S-H, C-N-S-H) is formed in the latter [18], further suggesting the importance of calcium and the phase in which it exists in the precursor. The inclusion of slag, which contains more vitreous calcium phases, into N-A-S$\mathrm{H}$ based systems has been shown to produce both types of binder gels. In these blended systems the "dominant" binder gel controls the diffusion, and some studies indicated that C-A-S-H gels can reduce chloride diffusion in N-A-S-H gel-based systems [52]. Similarly, in other binary systems with a higher weight percent of a precursor that produces $\mathrm{N}-\mathrm{A}-\mathrm{S}-\mathrm{H}$ gel, higher overall porosities have been reported $[36,71]$. However, in a system with FA and metakaolin, increasing the percentage of metakaolin by weight reduced average pore size due to the formation of more N-A-S-H gel [99], which could be attributed to the higher reactivity of metakaolin. Zhang et al. states that binary slag/metakaolin mixtures are chemically stable when immersed in seawater due to the structure of the aluminosilicate gel [33]. Contradictorily, there is evidence that $\mathrm{N}-\mathrm{A}-\mathrm{S}-\mathrm{H}$ gels of FA-based systems when immersed in seawater undergo cation exchange between $\mathrm{Na}$ and $\mathrm{Mg}$, thereby increasing the porosity of the system [100].

The increased formation of secondary reaction products, such as hydrotalcite and zeolites, is suggested to increase the chloride resistance of AACs. Hydrotalcite formation, for example, has been demonstrated to enhance chloride binding in slag-based AACs [101-103]. Hydrotalcite, due to its structure and large surface area, permits binding of anions. In slag-based AAC mixtures with high contents of $\mathrm{MgO}$ activated with $\mathrm{NaOH}$, hydrotalcite-like phases were observed by Ben Haha et al., and it has been further reported that high MgO systems will preferentially form hydrotalcite by reacting $\mathrm{Al}$ with $\mathrm{Mg}$ until all $\mathrm{Mg}$ has been exhausted [25,104106]. As a consequence, the production of hydrotalcite reduces the availability of $\mathrm{Al}$ for the formation of C-A-S-H and N-A-S-H gels $[106,107]$. Studies on the chloride uptake in hydrotalcite-like phases have yielded positive results, demonstrating the ability of these phases to uptake chlorides in highly alkaline solutions and in slag-based AACs $[101,108,109]$. Chloride uptake is sensitive to changes in $\mathrm{pH}$, chloride ion concentration, and strength of the pore solution [110]. One challenge is that, in some pure slag systems, hydrotalcite preferentially reacts with sulfate ions (from the potential decomposition of ettringite) instead of chlorides [111], if ettringite or other calcium sulfate phases are present in the system. Aside from hydrotalcite-like phases, some zeolites have been suggested to exhibit chloride-bearing potential [112]. Zeolites are aluminosilicate minerals (e.g., Faujasite, Mordenite) that occur in nature, and are often found in N-A-S-H based AAC [30,113]. Recent research by Jun et al. posits that alkali-activated FA contains other crystalline zeolite phases (e.g., Chabazite) that may be able to bear chlorides [112]. Gevaudan et al. shows that high silica availability, and high alkali content lead to high degrees of zeolitization [30]. Other authors have shown that mineralization can be induced in $\mathrm{N}$-A-S-H-based systems with the addition of organic compounds and other mineral additives [114-116].

\subsection{Chemical activators}

Activating solutions generally contain (1) silica, often in the form of liquid sodium silicate ( $\mathrm{NaSi}$ ) solution, (2) alkali hydroxides, which not only provide the necessary high $\mathrm{pH}$ for activation, but also provide charge-balancing cations (e.g., $\mathrm{Na}^{+}, \mathrm{K}^{+}, \mathrm{Ca}^{2+}$ ), and (3) water. Common activators include sodium hydroxide $(\mathrm{NaOH})$, potassium hydroxide $(\mathrm{KOH})$, and $\mathrm{NaSi}$ solutions. Additionally, calcium hydroxide $\left(\mathrm{Ca}(\mathrm{OH})_{2}\right)$ [28], solid silicates (e.g., sodium metasilicate pentahydrate), and sodium-carbonate have also been used for activating aluminosilicate precursors.

Silica content, silica speciation, the choice of alkali metal, and their respective concentrations in alkali-activating solutions directly affects dissolution, precipitation, and, hence, the subsequent gelation and formation of different aluminosilicate binder gels. However, explicit mechanisms for how these activators influence hardened state properties, including chloride transport, needs further refinement [117]. For example, reactions with sodium carbonate as activators are generally less reactive due to the acidic nature of the carbonate anion compared to reactions with hydroxides [118]. In addition, different metal cations (i.e., $\mathrm{Na}^{+}, \mathrm{K}^{+}, \mathrm{Ca}^{2+}$ ) present in activating solutions have been noted to influence porosity and degree of dissolution [119,120]. Furthermore, the initial content and phase of the activator (liquid or solid) affects the microstructural development of AACs and properties that affect chloride transport $[30,65,121]$. Each of these factors are discussed in the following sections.

\subsubsection{Silica content}

Silica content has been defined in the literature as the amount of total silica in either the activating solution alone or the entire $A A C$ system. The total quantity of silica in an AAC system is expressed as either the $\mathrm{Si} / \mathrm{Al}$ or $\mathrm{SiO}_{2} / \mathrm{Al}_{2} \mathrm{O}_{3}$ molar ratios. Oftentimes, however, the quantity of silica in the precursor is assumed to be a fixed amount and, thus, only the additional silica is reported as the silica modulus (Ms), or the ratio of $\mathrm{SiO}_{2}: \mathrm{Na}_{2} \mathrm{O}$, in the activating solution.

Increasing available silica in activating solutions has been shown to lead to reduced pore sizes, regardless of precursor chemistry and, often, reduced porosity. In FA-based systems, for example, additional silica promotes the development of finer pore networks, reduced porosity, and, thus, reduced water permeability 
(generally $\mathrm{Si}: \mathrm{Al} \geq 1.50)[19,43]$. Similar trends have been reported for slag-based systems [46]. Ye et al. [27] and Melo et al. [23] showed that higher silica content reduces porosity and results in a pore network with a smaller average pore size in slag-based AACs (in contrast, slags without added silica lead to unrefined pore systems [24,27]). Likewise, for metakaolin-based systems, Duxson et al. showed that $\mathrm{Si} / \mathrm{Al}$ ratios less than 1.4 lead to higherporosity systems [29], where many pores are interconnected, while $\mathrm{Si} / \mathrm{Al}$ ratios greater than 1.65 result in smaller pores distributed in a more homogenous pore system.

In fact, data show that increased silica content, in general, correlates with reduced chloride diffusivity in AACs, regardless of precursor. Increasing the Ms in FA-based AACs, for example, resulted in comparable chloride resistances of OPC and blended cements. However, the initial $\mathrm{pH}$ of these systems was insufficient to passivate the steel reinforcement or maintain a constant diffusion coefficient in the long term [57], demonstrating a durability tradeoff between a dense microstructure and passivation ability. In contrast, slag-based AAC systems with increased Ms have exhibited lower rapid chloride penetration test (RCPT) values and permeability values compared to OPC and improved non-steady-state diffusion behavior $[61,66,122]$. In binary FA-slag and bagasse ash-china clay systems, increased available silica content played a role in reducing chloride intrusion [32,39], further substantiating the important role of silica-containing activators. However, in studies on slag-based AACs, a Ms of 1.25 increased sorptivity due to the evolution of microcracks that can occur $[46,64]$, which are well known to exacerbate chloride diffusion [123].

Experimental evidence suggests that the form in which silica is added (e.g., anhydrous sodium metasilicate, sodium silicate, colloidal silica, soda glass) will influence AAC reaction kinetics, microstructural development, and, consequently, its transport properties. Behfarnia et al. incorporated both micro- and nanosilica into slag-based systems in identical percentages and observed higher chloride resistance with the addition of microsilica only [69]. In a metakaolin-based system, Gevaudan et al. studied the influence of silica by adding either solid soda glass or a liquid (NaSi). The availability of silica from liquid $\mathrm{NaSi}$ enabled expeditious gel formation and reduced porosity in systems with the same $\mathrm{SiO}_{2}: \mathrm{Na}_{2} \mathrm{O}$ ratio compared to the solid silica-containing samples [30]. Ravikumar et al. utilized a solid and liquid form of NaSi, which led to a variety of different, inconclusive performances of slagbased cements in terms of chloride diffusion [65]. While the use of liquid NaSi reduced overall porosity, the mixture activated with anhydrous NaSi exhibited improved chloride resistance, which the authors attributed to changes in pore structure, pore solution chemistry, and resulting ionic conductivity [65]. Although the effects of silica speciation are known to affect reaction kinetics [124], understanding the relationship between silica chemistry and durability remains a fundamental challenge for the field.

\subsubsection{Alkali content}

Expressed in different forms throughout the literature, alkali content, in general, refers to the quantity of elemental alkali metals (i.e., $\mathrm{Na}^{+}, \mathrm{K}^{+}, \mathrm{Ca}^{2+}$ ) in the activator. Alkali content has been defined as the molarity of the solution (i.e., $4 \mathrm{M} \mathrm{NaOH}$ ), the percentage of metal oxide by weight of precursor (i.e., $\mathrm{Na}_{2} \mathrm{O}$ per $\mathrm{g}$ of binder), or, in the case of liquid NaSi, the Ms of the solution (i.e., Ms = 2.0).

Experimental evidence substantiates that higher alkali content (generally $\mathrm{Na}: \mathrm{Al} \geq 0.75$ ) promotes rapid dissolution of precursors and, hence, reduces chloride transport in all precursor systems due to a reduction in porosity. Higher alkali contents in both FAand slag-based AACs have reduced porosities and reduced pore sizes, as indicated by lower water permeability and sorptivity of the samples $[19,59,65]$. However, when alkali content is held constant, porosity and average pore sizes are variably affected by the type of alkali metal cations, regardless of precursor [15,47,117]. The observed lower porosities can be attributed to higher alkal content promoting a more rapid dissolution of the precursor $[30,94,124-126]$. The increase in chloride resistance due to reductions in total pore volume and pore sizes observed with a higher alkali content has also been observed (and discussed previously) with increases in silica content. Moreover, in FA-based systems, higher alkali content decreased the chloride diffusion coefficient, as expected, and affected the quantity of both free and bound chlorides in the cementitious matrix [56]. In slag-based AACs, increasing alkali concentration and holding the other factors constant (i.e. Ms, curing time), resulted in significant reductions to RCPT values were observed [67]. Reductions in RCPT values have been correlated with observed reductions in the coefficient of non-steadystate diffusion with increasing alkali content [66]. Lastly in MK systems, higher alkali content - more than silica content - influenced the development of zeolitic crystalline phases that reduced overall porosity [30].

Alkalis from precursors and activators change the pore solution chemistry, which affects chloride intrusion and the ability of AACs to passivate steel. FA-based mixtures can provide adequate passivation to reinforcing steel, according to Bastidas et al. [127] and Criado et al. [43]. However, passivation has been shown to depend on the type of activator, the dosage, and the alkalinity of the solution such as utilizing a liquid $\mathrm{NaSi}$ and $\mathrm{NaOH}$ solution versus a solid $\mathrm{NaSi}$ and sodium carbonate activator due to the changes in the overall $\mathrm{pH}$ of the pore solution [87,126,128-130]. These findings are also applicable to slag-based (and some blended) mixtures, where high metal cation concentrations in the pore solution indicate the slag's ability to passivate steel $[21,61]$. For example, FA and slag mixtures with a higher volume of pores than a comparable OPC mixture exhibited lower susceptibilities to chloride ingress, which was attributed by the authors to repulsive ionic interactions between chlorides and pore solution chemistry [52].

\subsubsection{Water content}

Water content in OPC and AAC systems typically refers to the ratio of water to cementitious binder. However, depending on the system, whether it be paste, mortar, or concrete, water content can also be presented as the ratio of total liquid to total solids (L:S) used in the mixture.

Lower water-to-binder ratios reduce overall porosity in all AACs; however, experimental evidence also suggests that lower water-tobinder ratios reduce average pore sizes in slag-based AACs. In FAbased systems, decreased water contents have been correlated with lowered porosities $[35,127]$, with the caveat that lowering water content increases binder viscosity, which can lead to air entrapment in the mixture [17]. In terms of average pore size, while both Zhu et al. [35] and Bastidas et al. [127] note no significant differences when decreasing water content, Skvára et al. [17] reports a decrease in average pore size with decreasing water content. Related studies have suggested that insufficient water may lead to lower reactivity [131]. In slag-based AACs, water content imparted similar effects on porosity compared to $\mathrm{FA}$; however, water content might have a greater role in altering pore size [132]. Lower-water systems have been proven to exhibit improved chloride resistance and decreased water and chloride permeability $[32,35]$. Changes in average pore size is observed in binary FA/slag mixtures and in mixtures containing slag/metakaolin [35]. In all binary cases, the higher the slag content, the more evident the effect water content has on reduced porosity and average pore size [33].

\subsection{Curing regimes}

Heat curing in AACs is well known to lead to increased reactivity, reduced porosities, and reduced average pore sizes. Microstruc- 
tural differences develop due to changes in the kinetics of the reaction. Higher temperatures promote increased precursor dissolution and affect the overall generation of reaction products [124-126]. Higher curing temperatures, in general, reduce porosity, sorptivity, and chloride penetration in AACs regardless of precursor. In alkaliactivated FA, water permeability was reduced with longer periods of heat curing [19]. Curing at temperatures higher than $60^{\circ} \mathrm{C}$ and lower than $75^{\circ} \mathrm{C}$ decreased the volume of permeable pores and decreased sorptivity, which is used in the literature as an indicator of higher tortuosity $[19,76]$. Heat curing has also decreased permeability in some natural clay-based AACs, which was attributed by the authors to initial existence of water (due to polycondensation) that enhanced crosslinking and induced subsequent blockage of pores, which led to reduced chloride ion penetration [70].

Exploratory studies have elucidated that, unlike temperature, other curing conditions (e.g., time, humidity) may impart differences to each individual precursor/activator combination, but these variables have largely remained unexplored in the surveyed literature. Humidity conditions, for example, change the water availability in the cement matrix and play a role in the kinetics and degree of reaction. Interestingly, a FA activated with $\mathrm{NaOH}$ exhibited reduced porosities when dry-cured as opposed to steam- or wet-cured [16], while FA-based binary systems cured in a submerged saline environment (full saturation) exhibited lower sorptivity and decreased chloride penetration, which was attributed to reduced leaching of pore solution during activation [133]. Additionally, the intrusion of salt into the matrix was found to be negligible [133]. Slag systems cured in high temperature and relative humidity above $80 \%$ performed better than air- and limewater-cured slag-based AACs [63]. Autoclaved slag cements (with no added silica and low $\mathrm{Na}_{2} \mathrm{O}$ dosages) produced under high pressure, high heat, and high relative humidity conditions exhibited low porosity. This reduction has been attributed to the increased reaction of slag particles during curing [49]. Therefore, while high humidity is generally beneficial, for some systems, high humidity may prove suboptimal in achieving desirable microstructures.

In the reviewed literature, while blended precursor systems (e.g., slag/FA) are generally cured between 20 and $30^{\circ} \mathrm{C}$, these curing regimes do not take into account the lower rate of dissolution of FA at those temperatures or the different humidities at which they must be cured. For example, FA is optimally cured at temperatures $>60^{\circ} \mathrm{C}$ with [125] showing isothermal conduction calorimetry data that points to the low reactivity of FA when cured at temperatures lower than $30^{\circ} \mathrm{C}$. [15] showed that FA activated with $\mathrm{NaOH}$ should be dry-cured. AAC chloride transport literature has yet to address the interactions of curing regimes with the physicochemical characteristics of blended precursors and the impact those interactions have on chloride diffusion and chloride binding.

\section{Descriptive statistics of porosity and chloride diffusion}

This section statistically describes data from the reviewed literature in order to (1) analyze the most studied experimental parameters, (2) discuss the variability of those parameters, and (3) elucidate porosity and chloride diffusion differences by AAC precursor. Variability of chloride diffusion measurements is supplemented with discussions on the limitations of current characterization methods. (a) Paste

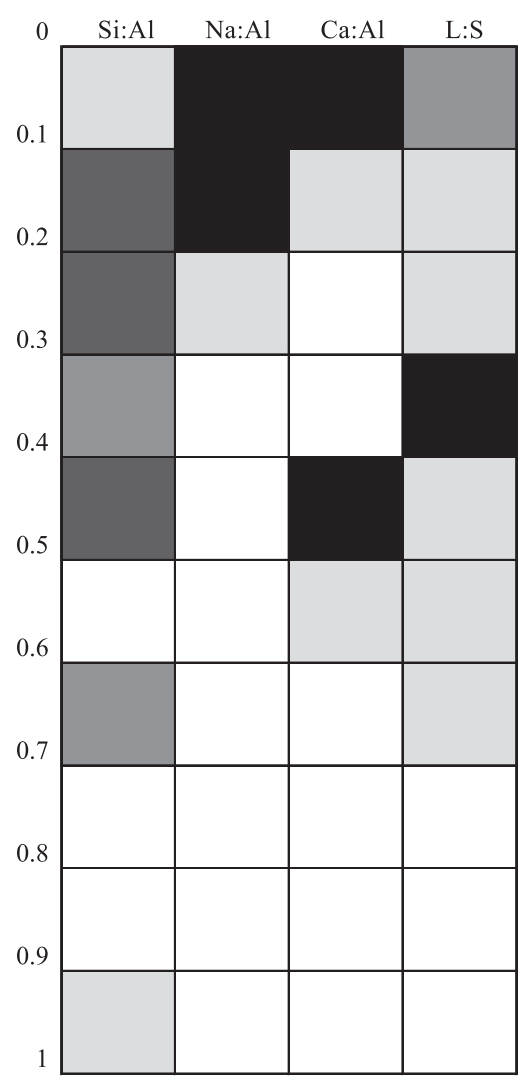

(b) Mortar

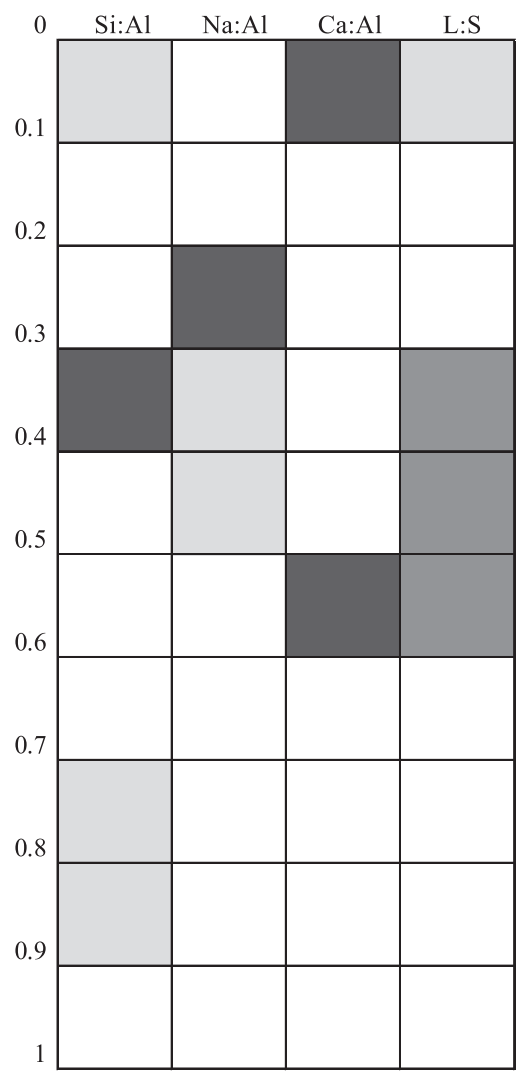

(c) Concrete

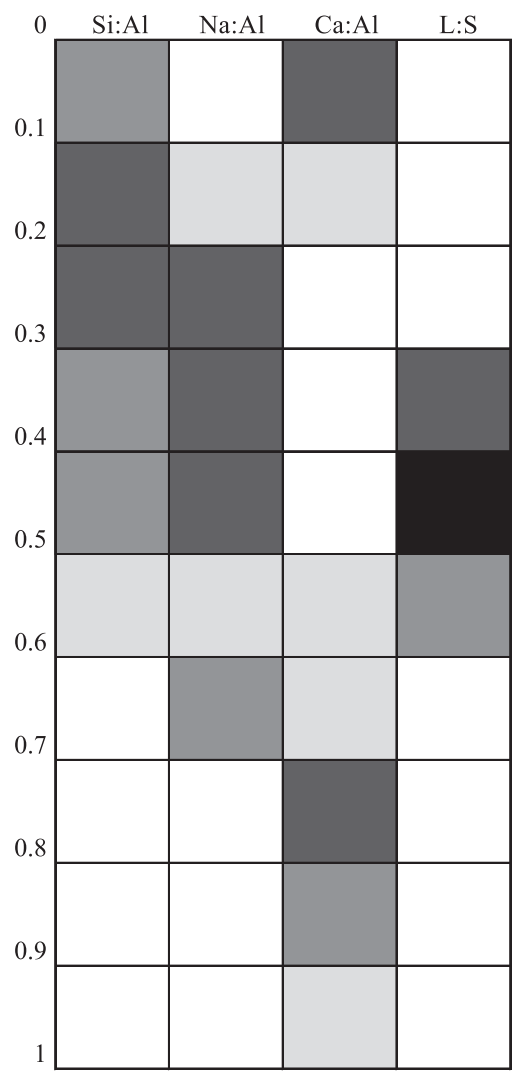

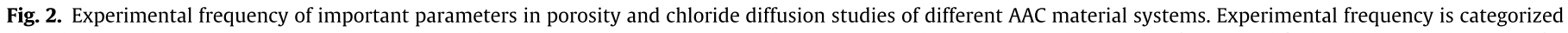

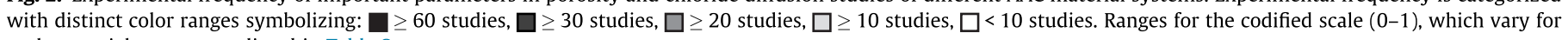
each material system, are listed in Table 2. 


\subsection{Experimental parameter mapping}

Fig. 2 quantitatively summarizes the ranges of common experimental parameters explored in the reviewed literature through a codified scale (from 0 to 1 ). The scales correspond to actual magnitudes that vary for each parameter (see Table 2). For example, the most studied L:S ratio in pastes lies between codified values of 0.3 and 0.4 , as shown in Fig. 2. Based on Table 2, these codified values correspond to L:S ratios between 0.17 and 0.24 . Fig. 2 illustrates that marked differences exist in the ranges of experimental parameters ( $\mathrm{Si}: \mathrm{Al}$ ratio, $\mathrm{Na}: \mathrm{Al}$ ratio, curing temperature) that have been explored for different material systems (i.e., paste, mortar, concrete), which need be reconciled for appropriate comparisons between those systems. The data presented in Fig. 2, in addition to aiding explanation of reported material properties related to chloride transport (see Section 4.2), may serve as a useful research tool for further experimentation of theoretical and practical studies on the chloride diffusion of AAC paste, mortar, and concrete.

In the literature, paste and mortar studies have a wider range of $\mathrm{Si}: \mathrm{Al}$ and $\mathrm{Na}: \mathrm{Al}$ ratios, while $\mathrm{Ca}: \mathrm{Al}$ and $\mathrm{L}: \mathrm{S}$ ratios remain largely unvaried in all three systems. Pastes generally explore these wider ranges of $\mathrm{Na}: \mathrm{Al}$ and $\mathrm{Si}: \mathrm{Al}$ ratios to understand microstructural development. However, the majority of $\mathrm{Ca}^{2+}$ comes from the usage of slag, given that $\mathrm{Ca}^{2+}$ that is rarely supplemented in these systems. Across all parameters in the reviewed studies, AAC pastes have been investigated with large ranges when compared to $A A C$ mortar and AAC concrete. For example, Na:Al ratios for paste $(0.0-1.0)$ have a larger range than mortars and concrete, 0.4-0.6 and $0.5-1.2$, respectively. In AAC concretes $\mathrm{Si}: \mathrm{Al}$ and Na:Al ratios have been explored at wider ranges than paste and mortars in the reported literature. For example, AAC paste samples explore $\mathrm{Si}: \mathrm{Al}$ and $\mathrm{Na}: \mathrm{Al}$ ratios at ranges of $1.1-2.0$ and $0.0-1.0$, respectively,

Table 2

Range of codified values and parameter values explored in Fig. 2. Paste outliers are the following: $\mathrm{Si}: \mathrm{Al}>5(7), \mathrm{Na}: \mathrm{Al}>5(1), \mathrm{Ca}: \mathrm{Al}>6(6)$. Mortar outliers are the following: $\mathrm{Si}: \mathrm{Al}>$ $5(0), \mathrm{Na}: \mathrm{Al}>5(1), \mathrm{Ca}: \mathrm{Al}>6(1), \mathrm{L}: \mathrm{S}>1(3)$.

\begin{tabular}{|c|c|c|c|c|c|c|c|c|c|c|c|c|}
\hline \multirow[t]{2}{*}{ Codified Values } & \multicolumn{4}{|l|}{ Paste } & \multicolumn{4}{|c|}{$\underline{\text { Mortar }}$} & \multicolumn{4}{|c|}{ Concrete } \\
\hline & Si:Al & $\mathrm{Na}: \mathrm{Al}$ & $\mathrm{Ca}: \mathrm{Al}$ & $\mathrm{L}: \mathrm{S}$ & Si:Al & $\mathrm{Na}: \mathrm{Al}$ & $\mathrm{Ca}: \mathrm{Al}$ & $\mathrm{L}: \mathrm{S}$ & Si:Al & $\mathrm{Na}: \mathrm{Al}$ & Ca:Al & $\mathrm{L}: \mathrm{S}$ \\
\hline$\Delta$ & 0.43 & 0.50 & 0.60 & 0.065 & 0.35 & 0.18 & 0.49 & 0.06 & 0.40 & 0.24 & 0.34 & 0.07 \\
\hline 0 & 0.69 & 0.00 & 0.00 & 0.15 & 0.39 & 0.04 & 0.0 & 0.21 & 1.54 & 0.01 & 0.01 & 0.18 \\
\hline 1 & 5.00 & 5.00 & 6.00 & 0.80 & 3.84 & 1.85 & 4.88 & 0.80 & 5.51 & 2.40 & 3.45 & 0.88 \\
\hline
\end{tabular}
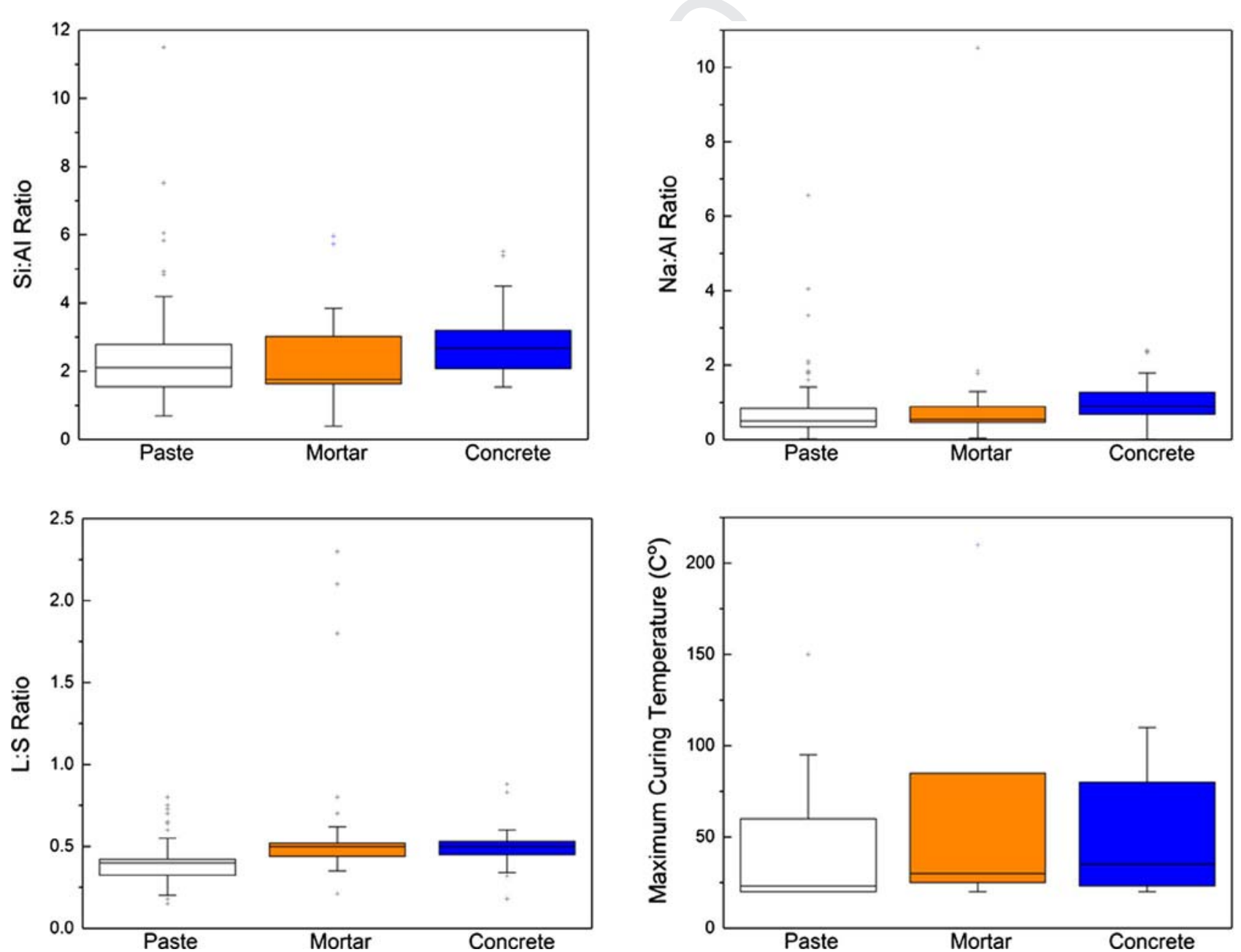

Fig. 3. Investigated experimental parameters across AAC material systems (i.e., paste, mortar, and concrete) regardless of AAC precursor. Median data are represented by centerlines in the box plots. 
and AAC concrete are mostly studied at $\mathrm{Si}: \mathrm{Al}$ and $\mathrm{Na}: \mathrm{Al}$ ratios of $1.9-2.7$ and $0.5-1.2$, respectively. Contrastingly, minimal differences exist between $\mathrm{Ca}: \mathrm{Al}$ and $\mathrm{L}: \mathrm{S}$ ratios explored in the different material systems, which is due to the fact that the primary source of calcium in all studies is from fairly similar slags. The aforementioned ratios tend to be explored in the following ranges: $0.0-0.5$ (Ca:Al ratio) and 0.4-0.6 (L:S). Although Fig. 2 provides useful information in terms of what parameters have been studied, the literature does not provide quantities of reactive silica, alumina, and calcium in their material systems, which means for more highly crystalline precursor systems, these values may be different than those reported [83].

Fig. 3 presents the distributions of the experimental parameters reported in the literature. The $\mathrm{L}: \mathrm{S}$ ratio remains relatively unchanged between systems as evidenced by the small variation in the mean. However, means of experimental parameters for $\mathrm{Si}$ : $\mathrm{Al}$ ratio, $\mathrm{Na}: \mathrm{Al}$ ratio, and maximum curing temperature vary widely between material systems. The means of Si:Al ratios increase from paste (2.46) to concrete (2.73) systems, but decreases for AAC mortars (2.11). A similar trend is observed in the means of $\mathrm{Na}$ :Al ratios in paste (0.69) and concrete (0.95) mixtures with a decrease in AAC mortars (0.73). Finally, the means of maximum curing temperature vary from $37.4{ }^{\circ} \mathrm{C}$ to $75.2^{\circ} \mathrm{C}$ to $47.6^{\circ} \mathrm{C}$ for paste, mortar, and concrete, respectively. Contrastingly, the means of L:S ratios for paste, mortar, and concrete $-0.39,0.50,0.49$, respectively-remain relatively unchanged. In addition, AAC concretes exhibit the least variation in Si:Al ratio, Na:Al ratio, L:S ratio, and maximum curing temperature when compared to AAC pastes and mortars (see Fig. 3), while AAC mortars exhibit the largest variations in $\mathrm{Na}: \mathrm{Al}$ ratios, L:S ratios, and maximum curing temperature. Curing regimes are chosen in a seemingly arbitrary manner. Reported here are the maximum curing temperatures, but each individual mixture often uses a different set of temperatures with varying durations and humidities.

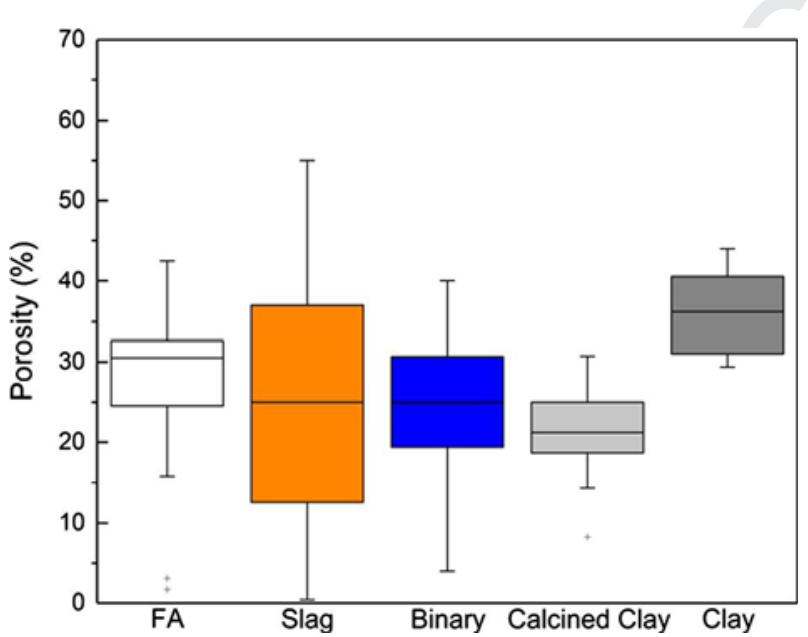

Fig. 4. AAC paste porosity by precursor. Outliers: FA $(3.13 \%, 1.67 \%)$ and calcined clay $(8.2 \%)$. Median data are represented by centerlines in the box plots.

\subsection{Porosity of AAC pastes by precursor}

Fig. 4 shows the average reported porosities of AAC pastes by aluminosilicate precursor. Depending on precursor, AAC pastes have comparable or lower porosities when compared to OPC pastes. From the reviewed literature, the average porosity of $A A C$ pastes is $26.7 \%$. In contrast, OPC paste studies (sans SCMs) report higher porosities of $30-34 \%[5,13,134]$. In some cases when different precursors are used, AAC porosities are reported to be higher than OPC. For example, average porosities of natural clay-based AACs (36.2\%) are higher than OPC (see Fig. 4), which is expected, due to the higher crystallinity and lower reactivity of natural clays. As a result, it is evident that, while porosities for AACs depend on the precursor, many have achieved comparable or lower porosities than OPC.

Statistical analysis of paste porosity data from the reviewed studies elucidate that increased exploration of experimental factors in AAC pastes yield high variability of porosities in the most oft-studied precursors (i.e., FA, slag, binary blends), as seen in Fig. 4. FA, slag, and binary mixtures comprise approximately $85 \%$ of all AAC pastes in the surveyed literature, and the effects of different processing factors (and ranges of those factors) have been more thoroughly studied in these precursors than in less common precursors, like calcined and uncalcined clays, resulting in a wider range of paste porosity data reported in the literature (see Section 4.1). Interestingly, slag has been reported to have among the lowest chemical variability of any other precursor (Fig. 1), yet slag-based AAC pastes exhibit the largest variation in reported paste porosity (Fig. 3). This variability in achievable paste porosities is likely due to the wide range of activation solution chemistries and processing conditions employed in the surveyed literature, emphasizing further need for a more critical and holistic understanding of the role that relevant factors, like activation solution chemistry and precursor reactivity, have on AAC paste porosity.

Descriptive statistics of the paste porosity data shown in Fig. 4 are summarized in Table 3. The statistical distribution of paste porosity data was evaluated using the Anderson-Darling (AD) goodness-of-fit statistical test for normality. The AD statistical test was modified to identify other possible distributions (i.e., exponential, Weibull, gamma, lognormal). Results show that the porosities of AACs made with binary blends, calcined clays, or clays can be described well using normal distributions. The normal distribution of the data may be due to the low sample number (clay and calcined clay groups) or the decreased factor effect affecting porosity (binary), but further research is needed to make more definitive conclusions. AD statistical test results were inconclusive for determining the distribution of the reviewed porosity data for both FAand slag-based AAC paste. Such a result may be due to the porosity variability arising from the effects of different processing factors (and ranges of those factors) in these highly studied precursors (see Section 4.1).

Significant mean porosity differences exist between clay-, calcined clay-, and FA-based AACs, while slag and binary mixtures exhibit similar mean porosities (Fig. 4). In order to differentiate

Table 3

Descriptive statistics for AAC paste porosity by precursor.

\begin{tabular}{|c|c|c|c|c|c|c|}
\hline Factor & $\mathrm{N}$ & Mean (\%) & 95\% Confidence Interval (\%) & Anderson-Darling Test (p-value) & Statistical Distribution & Games-Howell Grouping \\
\hline FA & 48 & $28.04 \pm 7.71$ & $(25.80,30.28)$ & $1.57(<0.005)$ & $\mathrm{N} / \mathrm{A}$ & A \\
\hline Slag & 68 & $24.27 \pm 15.0$ & $(20.63,27.91)$ & $0.92(0.018)$ & $\mathrm{N} / \mathrm{A}$ & A B \\
\hline Binary & 31 & $23.90 \pm 9.19$ & $(20.53,27.27)$ & $0.52(0.171)$ & Normal & A B \\
\hline Calcined Clay & 11 & $21.16 \pm 6.32$ & $(16.92,25.41)$ & $0.35(0.393)$ & Normal & B \\
\hline Clay & 15 & $36.18 \pm 4.96$ & $(33.43,38.93)$ & $0.33(0.463)$ & Normal & $\mathrm{C}$ \\
\hline
\end{tabular}

Histograms included in supplementary information. 
between mean porosities of precursors through an analysis of variance (ANOVA), the Levene statistical test was performed, which concluded that the porosity data have unequal variances between precursors ( $p$-value $<0.01$ ). As a result, the Welch statistical test was used to analyze mean differences. The normality assumption in this statistical test was not met by the porosity data of both FA and slag precursors, but it was deemed excusable due to robustness of the $t$-test statistic as evaluated by [135]. Results, shown in Table 3, demonstrate that natural clay-, calcined clay-, and FAbased AACs have distinct mean porosities than other AAC precursors. As expected, the mean porosity of natural clay-based AACs were highest of any other precursor, given the lower chemical reactivity of natural clay compared to other aluminosilicate precursors.

\subsection{Chloride diffusion of $A A C$ concrete by precursor}

Fig. 5 shows the average reported porosities of AAC pastes by aluminosilicate precursor. Generally, FA and slag-based (binary) AAC concrete materials have superior chloride diffusion coefficients when compared to OPC concrete. The chloride diffusion of $\mathrm{OPC}$ concrete is reported to be between $1 \mathrm{E}$ and 11 and $1 \mathrm{E}-12 \mathrm{~m}^{2} /$ s without use of SCMs $[52,74,136]$. In contrast, similarly to AAC porosities, chloride diffusion coefficients largely vary by precursor. For example, clay-based AAC concrete has the most unfavorable chloride-diffusion coefficient, which is again expected, as claybased AAC pastes possess the highest porosities amongst all pastes due to the lower reactivity of clays (Fig. 3).

Statistical data of chloride diffusion coefficients of AAC concrete reported in the reviewed literature shown in Fig. 5 are summarized in Table 4. In contrast to the paste porosity data presented in Section 4.2, slag-based AAC concretes have exhibited lower variability than fly-ash based AAC concretes in terms of chloride diffusion

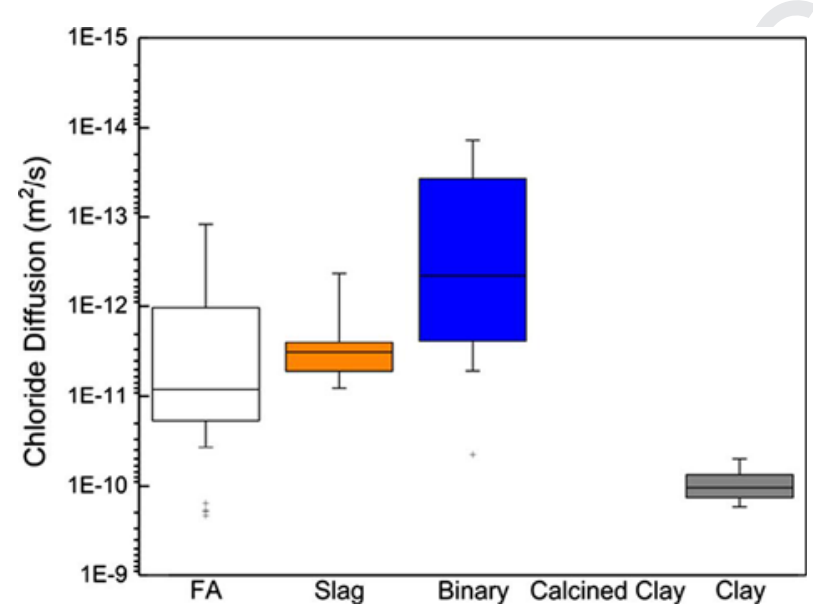

Fig. 5. AAC concrete chloride diffusion coefficient by precursor. No data available on calcined clay-based AAC concrete. Median data are represented by centerlines in the box plots. coefficient (Fig. 5). As seen in Table 4, chloride diffusion coefficients of slag- and clay-based AAC concrete were found to be described well using a normal distribution, while diffusion coefficients of binary blends were described well using a Weibull distribution. As previously performed for AAC paste porosity data (Table 3), the statistical distribution of chloride diffusion coefficients was determined using the Anderson-Darling (AD) statistical test for normality. The AD statistical test was modified to identify other possible distributions, yet results were inconclusive for the chloride diffusion data of FA-based AACs. No data yes exist on the chloride diffusion of calcined clay (i.e., metakaolin) AAC concrete.

As seen in Table 4, all precursors exhibit uniquely different means in chloride diffusion coefficient, with binary blends having similar chloride diffusion coefficients to both fly ash- and slagbased AACs. Similar to the statistical analysis of porosity data (Table 3), the Levene test was used to test the null hypothesis of equal variances, which was rejected and the alternative hypothesis was accepted (p-value $<0.01$ ). As determined by the GamesHowell means difference comparison, seen in Table 4, all AAC precursors had statistically different mean chloride diffusion coefficients with the exception of binary blends, which had a statistically similar means to both slag- and FA-based AAC concrete. As was the case in the previous analysis of porosity, the normality assumption in these statistical tests was not met by the chloride diffusion coefficient data for both FA and binary blend concrete, but it was deemed excusable due to robustness of the $t$-test statistic, as evaluated by [135]. Results shown in Tables 3 and 4 demonstrate that natural clay-based AACs have the highest mean paste porosity and chloride diffusion of any other AAC precursors. Again, this result is to be expected, given the lower amorphous contents and, thus, lower reactivity of uncalcined clays versus calcined clays and other industrial aluminosilicate precursors, like FA and slag.

\section{Challenges and opportunities in the study of chloride intrusion in AACs}

Despite advances in experimental studies that investigate chloride transport in AAC materials, a number of challenges and development opportunities exist to further scientific understanding of chloride transport in AACs and to fully elucidate similarities and differences between the chloride resistances of AAC and OPC paste, mortar, and concrete. For example, current test methodologies that are employed to study the chloride transport properties of AAC paste, mortar, and concrete are based on tests that were previously developed for OPC-based binders and do not account for the differences in the chemistry of AAC binders. New methods and advanced characterization techniques, like $\mathrm{X}$-ray micro-computed tomography, provide opportunities for more accurate measures of transport-relevant properties. Together, these improved methods and tools will likely lead to new materials science approaches to minimize chloride transport, such as enhancing chloride binding in AAC binders. The following sections discuss these challenges and potential opportunities in more detail.

Table 4

Descriptive statistics for AAC concrete chloride diffusion coefficient by precursor.

\begin{tabular}{|c|c|c|c|c|c|c|}
\hline Factor & $\mathrm{N}$ & Mean $\left(\mathrm{m}^{2} / \mathrm{s}\right)$ & 95\% Confidence Interval & Anderson-Darling Test (P-value) & Statistical Distribution ${ }^{*}$ & Games-Howell Grouping \\
\hline FA & 43 & $2.63 \mathrm{E}-11 \pm 5.42 \mathrm{E}-11$ & $(9.6 \mathrm{E}-12,4.3 \mathrm{E}-11)$ & $9.11(<0.005)$ & $\mathrm{N} / \mathrm{A}$ & A \\
\hline Slag & 33 & $3.73 \mathrm{E}-12 \pm 1.98 \mathrm{E}-12$ & $(3.0 \mathrm{E}-12,4.4 \mathrm{E}-12)$ & $0.46(0.247)$ & Normal & B \\
\hline Binary & 10 & $5.46 \mathrm{E}-12 \pm 1.4 \mathrm{E}-11$ & $(0,1.5 \mathrm{E}-11)$ & $2.57(<0.005)$ & Weibull & A B \\
\hline Calcined Clay & 0 & $\mathrm{~N} / \mathrm{A}$ & $\mathrm{N} / \mathrm{A}$ & $\mathrm{N} / \mathrm{A}$ & $\mathrm{N} / \mathrm{A}$ & $\mathrm{N} / \mathrm{A}$ \\
\hline Clay & 10 & $1.06 \mathrm{E}-10 \pm 4.18 \mathrm{E}-11$ & $(7.6 \mathrm{E}-11,1.4 \mathrm{E}-10)$ & $0.27(0.602)$ & Normal & $\mathrm{C}$ \\
\hline
\end{tabular}

Histograms included in supplementary information. 


\subsection{Addressing limitations of chloride diffusion test methods}

While the strengths of chloride diffusion test methods lie in their ability to quantify relative increases or decreases in chloride penetration resistance, inherent limitations in physical, chemical, and electrical resistivity methods used to characterize chloride ingress can obfuscate and impart inaccuracies on the response by affecting factors (e.g., preconditioning, instrumentation, test duration, aggregate volume content, saturation degree, quantification, precursor and pore solution chemistry) that are important for determining actual chloride transport. For example, given that chloride transport is governed by three distinct mechanism, which all can contribute to chloride transport phenomena, each test either isolates one mechanism or confounds multiple mechanisms into one measurement. Additional limitations of each type of characterization method are discussed in this section.

For physical characterization methods, the primary limitation concerns preconditioning regimes for C-A-S-H and N-A-S-H gel systems. Ismael et al. showed that preconditioning procedures associated with test methodologies in OPC concrete for porosity, water absorption, and permeability impart structural and chemical changes to AACs [137]. Therefore, the authors of [137] suggest that the selection of preconditioning methods should depend on the amount of bound water in the cement in an attempt to preserve the integrity of the binder gels. C-A-S-H gels tend to chemically bind water, while $\mathrm{N}-\mathrm{A}-\mathrm{S}-\mathrm{H}$ gels physically bind water, so the removal of water via vacuum or oven drying from $\mathrm{C}-\mathrm{A}-\mathrm{S}-\mathrm{H}$ gels leads to the potential for more structural damage. The authors recommend that C-A-S-H gel-based binders be preconditioned through a solvent exchange process utilizing acetone without the use of heat or vacuum, while, for N-A-S-H gels, vacuum drying paired with acetone for solvent exchange should be the primary preconditioning regime. In the same study, a 50/50 blend of LCFA and Slag cement showed no chemical changes upon oven dried, but some pore collapse was still noted, thereby suggesting that appropriate preconditioning regimes blended systems remain a significant challenge.

Chemical characterization methods often provide the most direct measurements of chloride diffusion; however, they are limited by the following factors. Ponding tests are typically conducted over a minimum of 90 days, and the chemical extraction processes are time-consuming. In addition, Yang et al. noted difficulty with precise differentiation between free and bound chlorides in AACs [37]. The effect of volume and type of aggregates in distorting diffusion coefficients adds to the difficulty of interpreting chemical characterization results $[44,68,138]$. Furthermore, while ASTM C642 has been the primary method of saturating specimens in the literature to attempt steady state diffusion, saturation is not always easily achieved [139]. For OPC concrete samples, Bu et al. [140] suggests vacuum-saturating specimens over a period of 24 $\mathrm{h}$ to ensure full concrete saturation. However, while this practice is not necessarily best for all AACs, as some are prone to microcracking (as noted above) and pore solution leaching, it provides a more accurate methodology for those AAC-based binders that can resist vacuum saturation. A potential methodological solution would consist of extracting AAC pore solution and creating a saturating solution with a near identical composition to minimize leaching.

Electrical characterization methods of chloride diffusion have been explored by many researchers. Bernal et al. [71], Balcikanli et al. [67], Shi et al. [46], and Andrade et al. [141] report that results of RCPT experiments are mainly dependent on pore solution chemistry as opposed to the nature of the pore structure. Noushini et al. verified the last assertion by finding that, while some AAC systems have denser matrices than their OPC counterparts, they exhibit relatively low resistivity values [142]. In addition, Ravikumar et al. reconciled the values of RCPT with those of non-steady state diffusion to understand any potential damage accelerated test methods might cause to the AAC microstructure due to the high temperatures induced by electrical currents [143]. Resistivity methods for measurement of chloride ions in AACs could be improved by modifying the work on of Weiss et al. [144] on OPC concrete, where pore solution is extracted and its resistivity is measured separately to create a correction factor for the resistivity of the cementitious binder. A methodology like this would aid in accounting for the variable pore solution chemistries of AACs.

In summary, results from physical, chemical, and electrical resistivity tests can vary due to limitations of those characterization methods. Despite these limitations, however, these standard methods of characterization, while developed for OPC concrete mixtures, have been essential to advance the state of knowledge regarding $A A C$ and chloride transport. Further research should use the best practices discussed here protect the microstructural integrity of the materials, and to obtain more realistic results.

\subsection{Advanced characterization techniques}

Chloride diffusion is a complex mechanism that often necessitates a suite of tests tailored to address challenges of varying length scales and other limitations explained herein. The use of advanced characterization methods, such as non-invasive X-ray micro-computed tomography $(\mu \mathrm{CT})$, are emerging as part of a new generation of methods being employed by researchers to attempt to fully characterize the microstructure of AAC and to relate microstructural understanding to resulting material properties that influence chloride transport. Provis et al. [34] and Long et al. [40]for example, employed a $\mu \mathrm{CT}$ to observe the development of AAC microstructure over time [34,40]. One advantage of $\mu C T$ is that it eliminates a need for sample pre-conditioning. Discontinuing harsh pre-conditioning regimes, as Ismail et al. recommend, will enable better understanding between indirect and direct testing [137]. This particular method does face its own challenges, however, in terms of time and data required to obtain fully characterized AAC pore networks. Additionally, Dehghan et al. [87] showed how to use electron microscopy and $\mu \mathrm{XRF}$ techniques to characterize how chloride ions travel through different high and low calcium binders. These techniques allow for simultaneous quantification of chlorides and chloride diffusion coefficients in the cementitious matrix utilizing a faster and less labor-intensive process than traditional methodologies, while providing maps of chloride intrusion and agglomeration in the sample. Currently these techniques are limited by the quality of available calibration curves and the sensitivity of the equipment [87].

Such improvements in characterization methods will result in a deepened understanding of the relationship between accelerated testing and in situ behavior. Additionally the work of Criado et al. implores future studies to take into account the redox potential of pore solution chemistries, since they will lead to different electrochemical signals $[128,145]$. This need, expressed by Duxson et al. in 2007, aims to move promising results from preliminary testing to field research, which is essential to substantiate realworld performance [146]. Additionally, due to its industry status as a new cementitious binder, more longitudinal studies need be performed on AACs to (1) understand how each influential factor described herein affects long-term microstructural development and both water and ion transport and (2) substantiate sufficient durability in both mild and aggressive environmental conditions.

\subsection{Enhancing chloride binding in AACs}

As previously discussed, the work of Ke et al. elucidated the chloride binding potential of hydrotalcite and hydrotalcite-like 
phases in carbonate-activated slags [101,108-110]. Although this work identifies mineral phases in slag based-AACs that bind chlorides and subsequently delay their transport through the pore network, more experimental work ought to be carried out to determine which phases of AACs, crystalline or amorphous, can bind, bear, or precipitate to reduce chloride diffusion. After identifying phases with exceptional chloride binding capacity, further experimental work should be dedicated to controlling and manipulating mineralization in AAC pastes to enable the preferential formation of those minerals and ultimately enhance chloride binding potential.

\section{Conclusion}

This review provides a process-structure-property assessment of the factors that impact chloride transport in alkali-activated cement (AAC) paste, mortar, and concrete. The reviewed literature indicates that physicochemical precursor characteristics, such as greater fineness and lower crystallinity, play a crucial role in dissolution, reactivity, and microstructural development of AACs leading to improved durability outcomes. Furthermore, the reviewed literature suggests that simply the presence of calcium alone in a precursor is not an indicator of improved chloride durability, but that the phase of the calcium (i.e., amorphous, semi-crystalline, crystalline) is perhaps a better predictor of increased durability. This behavior is particularly poignant when the durability of HCFA was compared to LCFA and slag AACs, where HCFAs were the worst performers. Understanding and predicting the behavior of blended AACs in terms of chloride durability remains a scientific challenge, because the physicochemical characteristics of amalgamated precursors result in different reaction kinetics and microstructural development.

Additionally, through a meta-analysis of published experimental data, the literature suggests that, in general, higher silica content ( $\mathrm{Si}: \mathrm{Al}$ ratio), higher alkali content ( $\mathrm{Na}: \mathrm{Al}$ ratio), lower water content ( $\mathrm{L}: \mathrm{S}$ ratio) improve chloride resistance. Contrastingly, while higher silica content is generally beneficial, experimental evidence suggests that it can lead to continued gelation in N-A-S$\mathrm{H}$ based AACs, creating a trade-off between beneficial lower porosities but detrimental reductions in pore solution. This continued gelation further suggests that a greater understanding of silica chemistry is necessary to address long-term chloride durability. Finally, as expected, heat curing improves porosity and, consequently, chloride resistance regardless of aluminosilicate precursors.

Evidenced by data from supporting literature, there is a clear need for overcoming limitations of chloride transport characterization methods that were developed for ordinary portland cement (OPC) concrete via advanced techniques, like X-ray computed micro-tomography and electron microprobe analysis, to better assess chloride transport in AAC paste, mortar, and concrete. Furthermore, improved mineralogical understanding of chloride binding is essential to advance scientific understanding and, ultimately, to inform the design and engineering of durable alkali-activated materials for applications in chloride-laden environments.

\section{Acknowledgments}

This research was made possible by the Department of Civil, Environmental, and Architectural Engineering, the College of Engineering and Applied Sciences, and the Sustainable Infrastructure Materials Laboratory (SIMLab) at the University of Colorado Boulder, with financial support from the National Science Foundation (NSF) (Award No. CBET-1604457) and the NSF Graduate Research Fellowship Program. The authors would also like to thank Prof.
Joseph Kasprzyk for his useful insights in data analysis tools. This work represents the views of the authors and not necessarily those of the sponsors.

1040 1041 1042

\section{References}

[1] G. Koch, J. Varney, N. Thompson, O. Moghissi, M. Gould, J. Payer, International measures of prevention, application, and economics of corrosion technologies study, NACE Int. (2016) 1-3 (accessed January 23, 2018).

[2] J.P. Broomfield, Corrosion of Steel in Concrete: Understanding, Investigation and Repair, Second Edition, CRC Press, 2006. doi:10.4324/9780203414606.

[3] F. Pacheco-Torgal, J. Castro-Gomes, S. Jalali, Alkali-activated binders: a review Part 1. Historical background, terminology, reaction mechanisms and hydration products, Constr. Build. Mater. 22 (2008) 1305-1314, https://doi. org/10.1016/j.conbuildmat.2007.10.015.

[4] F. Pacheco-Torgal, J. Castro-Gomes, S. Jalali, Alkali-activated binders: a review Part 2. About materials and binders manufacture, Constr. Build. Mater. 22 (2008) 1315-1322, https://doi.org/10.1016/j.conbuildmat.2007.03.019.

[5] F. Pacheco-Torgal, Z. Abdollahnejad, A.F. Camões, M. Jamshidi, Y. Ding, Durability of alkali-activated binders: a clear advantage over Portland cement or an unproven issue?, Constr Build. Mater. 30 (2012) 400-405, https://doi. org/10.1016/i.conbuildmat.2011.12.017.

[6] J.L. Provis, Alkali-activated materials, Cem. Concr. Res. (2016), https://doi.org/ 10.1016/j.cemconres.2017.02.009.

[7] L. Struble, E. Kim, L. Gómez-Zamorano, Overview of Geopolymer Cement, in: Geopolymer Bind. Syst., ASTM International, 100 Barr Harbor Drive, PO Box C700, West Conshohocken, PA 19428-2959, 2013: pp. 1-10. doi:10.1520/ STP156620120106.

[8] S.A. Bernal, J.L. Provis, Durability of alkali-activated materials: progress and perspectives, J. Am. Ceram. Soc. 97 (2014) 997-1008, https://doi.org/ $10.1111 /$ jace.12831.

[9] M.M. Hossain, M.R. Karim, M.K. Hossain, M.N. Islam, M.F.M. Zain, Durability of mortar and concrete containing alkali-activated binder with pozzolans: review, Constr. Build. Mater. 93 (2015) 95-109, https://doi.org/10.1016/ j.conbuildmat.2015.05.094.

[10] J. Zhang, C. Shi, Z. Zhang, Z. Ou, Durability of alkali-activated materials in aggressive environments: A review on recent studies, Constr. Build. Mater. 152 (2017) 598-613, https://doi.org/10.1016/j.conbuildmat.2017.07.027.

[11] R.D. Hooton, M.D.A. Thomas, K. Standish, Prediction of Chloride Penetration in Concrete., Toronto, 2001. https://trid.trb.org/view.aspx?id=690787 (accessed November 7, 2017).

[12] Y. Bu, J. Weiss, Saturation of air entrained voids and its implication on the transport of ionic species in concrete, 4th Int.Conf. Durab. Concr. Struct (2014), https://doi.org/10.5703/1288284315400.

[13] N.K. Lee, H.K. Lee, Influence of the slag content on the chloride and sulfuric acid resistances of alkali-activated fly ash/slag paste, Cem. Concr. Compos. 72 (2016) 168-179, https://doi.org/10.1016/j.cemconcomp.2016.06.004

[14] C. Monticelli, M.E. Natali, A. Balbo, C. Chiavari, F. Zanotto, S. Manzi, M.C Bignozzi, A study on the corrosion of reinforcing bars in alkali-activated fly ash mortars under wet and dry exposures to chloride solutions, Cem. Concr. Res. 87 (2016) 53-63, https://doi.org/10.1016/j.cemconres.2016.05.010.

[15] T. Bakharev, Resistance of geopolymer materials to acid attack, Cem. Concr. Res. 35 (2005) 658-670, https://doi.org/10.1016/j.cemconres.2004.06.005.

[16] G. Kovalchuk, A. Fernández-Jiménez, A. Palomo, Alkali-activated fly ash effect of thermal curing conditions on mechanical and microstructural development - Part II, Fuel 86 (2007) 315-322, https://doi.org/10.1016/ j.fuel.2006.07.010.

[17] F. Skvára, L. Kopec, V. Smilauer, Z. Bittnar, Material and structural characterization of alkali activated low-calcium brown coal fly ash, J Hazard. Mater. 168 (2009) 711-720, https://doi.org/10.1016/j. jhazmat.2009.02.089.

[18] F. Winnefeld, A. Leemann, M. Lucuk, P. Svoboda, M. Neuroth, Assessment of phase formation in alkali activated low and high calcium fly ashes in building materials, Constr. Build. Mater. 24 (2010) 1086-1093, https://doi.org/ 10.1016/j.conbuildmat.2009.11.007.

[19] Y. Ma, J. Hu, G. Ye, The pore structure and permeability of alkali activated fly ash, Fuel 104 (2013) 771-780, https://doi.org/10.1016/j.fuel.2012.05.034.

[20] P. Hlaváček, V. Šmilauer, F. Škvára, L. Kopecký, R. Šulc, Inorganic foams made from alkali-activated fly ash: mechanical, chemical and physical properties, J. Eur. Ceram. Soc. 35 (2015) 703-709, https://doi.org/10.1016/ j.jeurceramsoc.2014.08.024.

[21] D.M. Roy, W. Jiang, M. Silsbee, Chloride diffusion in ordinary, blended, and alkali-activated cement pastes and its relation to other properties, Cem. Concr. Res. 30 (2000) 1879-1884, https://doi.org/10.1016/S0008-8846(00) 00406-3.

[22] F. Collins, J.G. Sanjayan, Effect of pore size distribution on drying shrinkage of alkali-activated slag concrete, Cem. Concr. Res. 30 (2000) 1401-1406, https:/ doi.org/10.1016/S0008-8846(00)00327-6.

[23] A.A. Melo Neto, M.A. Cincotto, W. Repette, Drying and autogenous shrinkage of pastes and mortars with activated slag cement, Cem. Concr. Res. 38 (2008) 565-574, https://doi.org/10.1016/j.cemconres.2007.11.002.

[24] M. Ben Haha, G. Le Saout, F. Winnefeld, B. Lothenbach, Influence of activator type on hydration kinetics, hydrate assemblage and microstructural 
development of alkali activated blast-furnace slags, Cem. Concr. Res. 41 (2011) 301-310, https://doi.org/10.1016/j.cemconres.2010.11.016.

[25] M. Ben Haha, B. Lothenbach, G. Le Saout, F. Winnefeld, Cement and Concrete Research In fl uence of slag chemistry on the hydration of alkali-activated blast-furnace slag-Part I: effect of MgO, Cem. Concr. Res. 41 (2011) 955-963, https://doi.org/10.1016/j.cemconres.2011.05.002.

[26] F. Puertas, M. Palacios, H. Manzano, J.S. Dolado, A. Rico, J. Rodríguez, A model for the C-A-S-H gel formed in alkali-activated slag cements, J. Eur. Ceram. Soc. 31 (2011) 2043-2056, https://doi.org/10.1016/j.jeurceramsoc.2011.04.036.

[27] H. Ye, C. Cartwright, F. Rajabipour, A. Radlińska, Understanding the drying shrinkage performance of alkali-activated slag mortars, Cem. Concr. Compos. 76 (2017) 13-24, https://doi.org/10.1016/j.cemconcomp.2016.11.010.

[28] E.A. Ortega, C. Cheeseman, J. Knight, M. Loizidou, Properties of alkaliactivated clinoptilolite, Cem. Concr. Res. 30 (2000) 1641-1646, https://doi. org/10.1016/S0008-8846(00)00331-8.

[29] P. Duxson, J.L. Provis, G.C. Lukey, S.W. Mallicoat, W.M. Kriven, J.S.J. Van Deventer, Understanding the relationship between geopolymer composition, microstructure and mechanical properties, Colloids Surfaces A Physicochem. Eng. Asp. 269 (2005) 47-58, https://doi.org/10.1016/j.colsurfa.2005.06.060.

[30] J.P. Gevaudan, K.M. Campbell, T.J. Kane, R.K. Shoemaker, W.V. Srubar, Mineralization dynamics of metakaolin-based alkali-activated cements, Cem. Concr. Res. 94 (2017) 1-12, https://doi.org/10.1016/j. cemconres.2017.01.001.

[31] Z. Pan, D. Li, J. Yu, N. Yang, Properties and microstructure of the hardened alkali-activated red mud-slag cementitious material, Cem. Concr. Res. 33 (2003) 1437-1441, https://doi.org/10.1016/S0008-8846(03)00093-0.

[32] R.R. Lloyd, J.L. Provis, J.S.J. van Deventer, Pore solution composition and alkali diffusion in inorganic polymer cement, Cem. Concr. Res. 40 (2010) 1386 1392, https://doi.org/10.1016/j.cemconres.2010.04.008.

[33] Z. Zhang, X. Yao, H. Zhu, Potential application of geopolymers as protection coatings for marine concreteII. Microstructure and anticorrosion mechanism, Appl. Clay Sci. 49 (2010) 7-12, https://doi.org/10.1016/j.clay.2010.04.024.

[34] J.L. Provis, R.J. Myers, C.E. White, V. Rose, J.S.J. van Deventer, X-ray microtomography shows pore structure and tortuosity in alkali-activated binders, Cem. Concr. Res. 42 (2012) 855-864, https://doi.org/10.1016/j. cemconres.2012.03.004.

[35] H. Zhu, Z. Zhang, Y. Zhu, L. Tian, Durability of alkali-activated fly ash concrete: chloride penetration in pastes and mortars, Constr. Build. Mater. 65 (2014) 51-59, https://doi.org/10.1016/j.conbuildmat.2014.04.110.

[36] I. Ismail, S.A. Bernal, J.L. Provis, R. San Nicolas, S. Hamdan, J.S.J. Van Deventer, Modification of phase evolution in alkali-activated blast furnace slag by the incorporation of fly ash, Cem. Concr. Compos. 45 (2014) 125-135, https://doi. org/10.1016/j.cemconcomp.2013.09.006.

[37] T. Yang, X. Yao, Z. Zhang, Quantification of chloride diffusion in fly ash-slagbased geopolymers by X-ray fluorescence (XRF), Constr. Build. Mater. 69 (2014) 109-115, https://doi.org/10.1016/j.conbuildmat.2014.07.031.

[38] X. Yao, T. Yang, Z. Zhang, Compressive strength development and shrinkage of alkali-activated fly ash-slag blends associated with efflorescence, Mater. Struct. Constr. 49 (2016) 2907-2918, https://doi.org/10.1617/s11527-015 0694-3.

[39] L. Noor-ul-Amin, U. Nawab, Ghani, Synthesis and characterization of chloride resistant cement from industrial waste through geopolymerization, J. Clean. Prod. 156 (2017) 577-580, https://doi.org/10.1016/j.jclepro.2017.04.079.

[40] W. Long, B. Xiao, B. Zhou, P. Liang, Research on the internal pores in alkaliactivated slag cementing material via X-CT three-dimensional imaging microscopy, AIP Conf. Proc. (2017), https://doi.org/10.1063/1.4971883.

[41] D. Ren, C. Yan, P. Duan, Z. Zhang, L. Li, Z. Yan, Durability performances of wollastonite, tremolite and basalt fiber-reinforced metakaolin geopolymer composites under sulfate and chloride attack, Constr. Build. Mater. 134 (2017) 56-66, https://doi.org/10.1016/j.conbuildmat.2016.12.103.

[42] J.M. Miranda, A. Fernández-Jiménez, J.A. González, A. Palomo, Corrosion resistance in activated fly ash mortars, Cem. Concr. Res. 35 (2005) 12101217, https://doi.org/10.1016/j.cemconres.2004.07.030.

[43] M. Criado, D.M. Bastidas, S. Fajardo, A. Fernández-Jiménez, J.M. Bastidas, Corrosion behaviour of a new low-nickel stainless steel embedded in activated fly ash mortars, Cem. Concr. Compos. 33 (2011) 644-652, https:// doi.org/10.1016/j.cemconcomp.2011.03.014.

[44] S. Asprogerakas, Aristeidis Koutelia, Aristea Kakali, Glykeria Tsivilis, Durability of fly ash geopolymer mortars in corrosive environments, compared to that of cement mortars, Adv. Sci. Technol. 92 (2014) 84-89, https://doi.org/10.4028/www.scientific.net/AST.92.84.

[45] C. Monticelli, M.E. Natali, A. Balbo, C. Chiavari, F. Zanotto, S. Manzi, M.C. Bignozzi, Corrosion behavior of steel in alkali-activated fly ash mortars in the light of their microstructural, mechanical and chemical characterization, Cem. Concr. Res. 80 (2016) 60-68, https://doi.org/10.1016/j. cemconres.2015.11.001.

[46] C. Shi, Strength, pore structure and permeability of alkali-activated slag mortars, Cem. Concr. Res. (1996), https://doi.org/10.1016/S0008-8846(96) 00174-3.

[47] A.R. Brough, A. Atkinson, Sodium silicate-based, alkali-activated slag mortars - Part I. Strength, hydration and microstructure, Cem. Concr. Res. 32 (2002) 865-879, https://doi.org/10.1016/S0008-8846(02)00717-2.

[48] L. Zuda, P. Bayer, P. Rovnaník, R. Černý, Mechanical and hydric properties of alkali-activated aluminosilicate composite with electrical porcelain aggregates, Cem. Concr. Compos. 30 (2008) 266-273, https://doi.org/ 10.1016/j.cemconcomp.2007.11.003.
[49] S. Aydin, B. Baradan, Mechanical and microstructural properties of heat cured alkali-activated slag mortars, Mater. Des. 35 (2012) 374-383, https://doi.org/ 10.1016/j.matdes.2011.10.005.

[50] A. Palomo, M.T. Blanco-Varela, M.L. Granizo, F. Puertas, T. Vazquez, M.W. Grutzeck, Chemical stability of cementitious materials based on metakaolin, Cem. Concr. Res. 29 (1999) 997-1004, https://doi.org/10.1016/S0008-8846 (99)00074-5.

[51] M. Chi, R. Huang, Binding mechanism and properties of alkali-activated fly ash/slag mortars, Constr. Build. Mater. 40 (2013) 291-298, https://doi.org/ 10.1016/j.conbuildmat.2012.11.003.

[52] I. Ismail, S.A. Bernal, J.L. Provis, R. San Nicolas, D.G. Brice, A.R. Kilcullen, S. Hamdan, J.S.J. Van Deventer, Influence of fly ash on the water and chloride permeability of alkali-activated slag mortars and concretes, Constr. Build. $\begin{array}{llll}\text { Mater. } & 48 & \text { (2013) } & \text { 1187-1201, https://doi.org/10.1016/ }\end{array}$ j.conbuildmat.2013.07.106.

[53] M.R. Karim, M.M. Hossain, M.F.M. Zain, M. Jamil, F.C. Lai, Durability properties of a non-cement binder made up of pozzolans with sodium hydroxide, Constr. Build. Mater. 138 (2017) 174-184, https://doi.org/10.1016/ j.conbuildmat.2017.01.130.

[54] A. Arham, A.M. Sc, Strength and Durability Properties of Alkali Activated Slag and Fly Ash-Based Geopolymer Concrete, RMIT University, 2009.

[55] K. Kupwade-Patil, E.N. Allouche, Examination of Chloride-Induced Corrosion in Reindorced Geopolymer Concretes, J. Mater. Civ. Eng. 25 (2013), https:// doi.org/10.1061/(ASCE)MT.1943.

[56] P. Chindaprasirt, W. Chalee, Effect of sodium hydroxide concentration on chloride penetration and steel corrosion of fly ash-based geopolymer concrete under marine site, Constr. Build. Mater. 63 (2014) 303-310, https://doi.org/10.1016/j.conbuildmat.2014.04.010.

[57] D.W. Law, A.A. Adam, T.K. Molyneaux, I. Patnaikuni, A. Wardhono, Long term durability properties of class F fly ash geopolymer concrete, Mater. Struct. (2014) 1-11, https://doi.org/10.1617/s11527-014-0268-9.

[58] C. Gunasekara, D.W. Law, S. Setunge, Long term permeation properties of different fly ash geopolymer concretes, Constr. Build. Mater. 124 (2016) 352362, https://doi.org/10.1016/j.conbuildmat.2016.07.121.

[59] P. Nuaklong, V. Sata, P. Chindaprasirt, Influence of recycled aggregate on fly ash geopolymer concrete properties, J. Clean. Prod. 112 (2016) 2300-2307, https://doi.org/10.1016/j.jclepro.2015.10.109.

[60] L. Gunasekara, Chamila Bhuiyan, Shamir Law, David Setunge, Sujeeva Ward, Corrosion Resistance in Different Fly Ash Based Geopolymer Concretes, HPC/ CIC Tromsø 2017. (2017). https://www.researchgate.net/profile/David_Law8/ publication/314837264_Corrosion_resistance_in_different_fly_ash_ based_geopolymer_concretes/links/58ca415792851c4b5e6e36ec/Corrosionresistance-in-different-fly-ash-based-geopolymer-concretes.pdf (accessed May 9, 2017)

[61] S. Al-Otaibi, Durability of concrete incorporating GGBS activated by waterglass, Constr. Build. Mater. 22 (2008) 2059-2067, https://doi.org/10.1016/ j.conbuildmat.2007.07.023.

[62] N.G. Lim, S.W. Jeong, J.W. Her, K.Y. Ann, Properties of cement-free concrete cast by finely grained nanoslag with the $\mathrm{NaOH}$-based alkali activator, Constr.

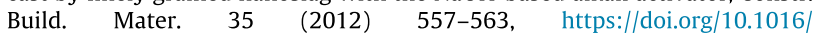
j.conbuildmat.2012.04.012.

[63] M. Chi, Effects of dosage of alkali-activated solution and curing conditions on the properties and durability of alkali-activated slag concrete, Constr. Build.

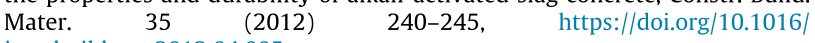
j.conbuildmat.2012.04.005.

[64] D.W. Law, A.A. Adam, T.K. Molyneaux, I. Patnaikuni, Durability assessment of alkali activated slag (AAS) concrete, Mater. Struct. Constr. 45 (2012) 14251437, https://doi.org/10.1617/s11527-012-9842-1.

[65] D. Ravikumar, N. Neithalath, Electrically induced chloride ion transport in alkali activated slag concretes and the influence of microstructure, Cem. Concr. Res. 47 (2013) 31-42, https://doi.org/10.1016/j.cemconres.2013.01.007.

[66] Q. Ma, S.V. Nanukuttan, P.A.M. Basheer, Y. Bai, C. Yang, Chloride transport and the resulting corrosion of steel bars in alkali activated slag concretes, Mater. Struct. 49 (2016) 3663-3677, https://doi.org/10.1617/s11527-015-0747-7.

[67] M. Balcikanli, E. Ozbay, Optimum design of alkali activated slag concretes for the low oxygen/chloride ion permeability and thermal conductivity, Compos. Part B Eng. 91 (2016) 243-256, https://doi.org/10.1016/ j.compositesb.2016.01.047.

[68] K. Parthiban, K. Saravana Raja Mohan, Influence of recycled concrete aggregates on the engineering and durability properties of alkali activated slag concrete, Constr. Build. Mater. 133 (2017) 65-72, https://doi.org/ 10.1016/j.conbuildmat.2016.12.050.

[69] K. Behfarnia, M. Rostami, Effects of micro and nanoparticles of SiO2on the permeability of alkali activated slag concrete, Constr. Build. Mater. 131 (2017) 205-213, https://doi.org/10.1016/j.conbuildmat.2016.11.070.

[70] D. Bondar, C.J. Lynsdale, N.B. Milestone, N. Hassani, Oxygen and chloride permeability of alkali-activated natural pozzolan concrete, ACI Mater. J. 109 (2012) 53-61 (accessed March 16, 2017) http://s3.amazonaws.com/ academia.edu.documents/41817782/Oxygen_and_chloride_permeability_of_ alka20160131-13812-3xlb0v.pdf?AWSAccessKeyId= AKIAIWOWYYGZ2Y53UL3A\&Expires $=1489612346 \&$ Signature $=G 0 \%$ 2FIroFcWijKjSw2O2ieDIY1LDU\%3D\&response-content-disposition=inline.

[71] S.A. Bernal, R. Mejía De Gutiérrez, J.L. Provis, Engineering and durability properties of concretes based on alkali-activated granulated blast furnace slag/metakaolin blends, Constr. Build. Mater. 33 (2012) 99-108, https://doi. org/10.1016/j.conbuildmat.2012.01.017. 
[72] S.A. Bernal, J.L. Provis, R. Mejía de Gutiérrez, J.S.J. van Deventer, Accelerated carbonation testing of alkali-activated slag/metakaolin blended concretes: effect of exposure conditions, Mater. Struct. 48 (2015) 653-669, https://doi. org/10.1617/s11527-014-0289-4.

[73] M. Albitar, M.S. Mohamed Ali, P. Visintin, M. Drechsler, Durability evaluation of geopolymer and conventional concretes, Constr. Build. Mater. 136 (2017) 374-385, https://doi.org/10.1016/j.conbuildmat.2017.01.056.

[74] C. Tennakoon, A. Shayan, J.G. Sanjayan, A. Xu, Chloride ingress and steel corrosion in geopolymer concrete based on long term tests, Mater. Des. 116 (2017) 287-299, https://doi.org/10.1016/j.matdes.2016.12.030.

[75] M. Babaee, A. Castel, Chloride-induced corrosion of reinforcement in lowcalcium fly ash-based geopolymer concrete, Cem. Concr. Res. 88 (2016) 96107, https://doi.org/10.1016/j.cemconres.2016.05.012.

[76] A. Noushini, A. Castel, The effect of heat-curing on transport properties of low-calcium fly ash-based geopolymer concrete, Constr. Build. Mater. 112 (2016) 464-477, https://doi.org/10.1016/j.conbuildmat.2016.02.210.

[77] W. Duan, M. Lopez, M.C.G. Juenger, K.L. Aughenbaugh, P. Stutzman, identifying glass compositions in Fly ash, Front. Mater. 3 (2016) 1, https:// doi.org/10.3389/fmats.2016.00001.

[78] M. Komljenović, Z. Baščarević, V. Bradić, Mechanical and microstructural properties of alkali-activated fly ash geopolymers, J. Hazard. Mater. 181 (2010) 35-42, https://doi.org/10.1016/j.jhazmat.2010.04.064.

[79] A. Fernández-Jiménez, A. Palomo, Characterisation of fly ashes. Potential reactivity as alkaline cements, Fuel. 82 (2003) 2259-2265, https://doi.org/ 10.1016/S0016-2361(03)00194-7.

[80] R.A. Helmuth, Fly Ash in Cement and Concrete, 1987. http://www.imcyc.com/ biblioteca/ArchivosPDF/Cenizas Volantes/Fly Ash in Cement and Concrete.pdf (accessed January 23, 2018).

[81] O.E. Manz, Coal fly ash: a retrospective and future look, Fuel 78 (1999) $133-$ 136, https://doi.org/10.1016/S0016-2361(98)00148-3.

[82] E.R. Dunstan, What is a "Practical" (ASTM C 618) SAI-Strength Activity Index for Fly Ashes that can be used to Proportion Concretes Containing Fly Ash? in: 2017 World Coal Ash Conf., Lexington, KY, 2017: p. 25. http://www.flyash. info/ (accessed January 22, 2018)

[83] J. Sweeney, T. Htut, W. Huen, V. Vimonsatit, Investigating Amorphous Composition Mix Design Performance and Properties of Fly Ash-Based Geopolymer, Electron. J. Struct. Eng. (2017). http://www.ejse.org/Archives/ Fulltext/2017/2017-1-5.pdf (accessed May 3, 2018).

[84] P. Nuaklong, V. Sata, P. Chindaprasirt, Properties of metakaolin-high calcium fly ash geopolymer concrete containing recycled aggregate from crushed concrete specimens, Constr. Build. Mater. 161 (2018) 365-373, https://doi. org/10.1016/j.conbuildmat.2017.11.152.

[85] C. Yi, H. Ma, H. Zhu, W. Li, M. Xin, Y. Liu, Y. Guo, Study on chloride binding capability of coal gangue based cementitious materials, Constr. Build. Mater. 167 (2018) 649-656, https://doi.org/10.1016/j.conbuildmat.2018.02.071.

[86] D.F. Velandia, C.J. Lynsdale, J.L. Provis, F. Ramirez, Effect of mix design inputs, curing and compressive strength on the durability of Na 2 SO 4 -activated high volume fly ash concretes, Cem. Concr. Compos. (2018), https://doi.org/ 10.1016/j.cemconcomp.2018.03.028.

[87] A. Dehghan, K. Peterson, G. Riehm, L. Herzog Bromerchenkel, Application of $\mathrm{X}$-ray microfluorescence for the determination of chloride diffusion coefficients in concrete chloride penetration experiments, Constr. Build. Mater. 148 (2017) 85-95. doi:10.1016/J.CONBUILDMAT.2017.05.072.

[88] K.C. Newlands, D.E. Macphee, The reactivity of aluminosilicate glasses in cements-effects of Ca content on dissolution characteristics and surface precipitation, Adv. Appl. Ceram. 116 (2017) 216-224, https://doi.org/ 10.1080/17436753.2017.1299986.

[89] R. Galibert, GLASS CONTENT INFLUENCE UPON HYDRAULIC POTENTIAL OF BLAST - FURNACE SLAG, Natl. SLAG Assoc. (n.d.) 5-8. http:// www.nationalslagassoc.org (accessed May 3, 2018).

[90] S.A. Bernal, M.C.G. Juenger, X. Ke, W. Matthes, B. Lothenbach, N. De Belie, J.L. Provis, Characterization of supplementary cementitious materials by thermal analysis, Mater. Struct. 50 (2016) 1-13, https://doi.org/10.1617/s11527-0160909-2.

[91] D. Khale, R. Chaudhary, Mechanism of geopolymerization and factors influencing its development: a review, J. Mater. Sci. 42 (2007) 729-746, https://doi.org/10.1007/s10853-006-0401-4.

[92] A. Shvarzman, K. Kovler, G.S. Grader, G.E. Shter, The effect of dehydroxylation/ amorphization degree on pozzolanic activity of kaolinite, Cem. Concr. Res. 33 (2003) 405-416, https://doi.org/10.1016/S0008-8846(02)00975-4.

[93] G. Bumanis, L. Vitola, D. Bajare, L. Dembovska, I. Pundiene, Impact of reactive $\mathrm{SiO} / \mathrm{Al} 2 \mathrm{O}$ ratio in precursor on durability of porous alkali activated materials, Ceram. Int. 43 (2017) 5471-5477, https://doi.org/10.1016/j. ceramint.2017.01.060.

[94] M. Najimi, N. Ghafoori, M. Sharbaf, Alkali-activated natural pozzolan/slag mortars: a parametric study, Constr. Build. Mater. 164 (2018) 625-643, https://doi.org/10.1016/j.conbuildmat.2017.12.222.

[95] M. Najimi, N. Ghafoori, B. Radke, K. Sierra, M. Sharbaf, Comparative Study of Alkali-Activated Natural Pozzolan and Fly Ash Mortars, J. Mater. Civ. Eng. 30 (2018) 04018115, https://doi.org/10.1061/(ASCE)MT.1943-5533.0002306.

[96] J.L. Provis, A. Palomo, Advances in understanding alkali-activated materials, Cem. Concr. Res. 78 (2015) 110-125, https://doi.org/10.1016/j. cemconres.2015.04.013.

[97] M.A.M. Ariffin, M.W. Hussin, Chloride resistance of blended ash geopolymer concrete, J. Civ. Eng. Sci. Technol. 6 (2015) 23-33.
[98] R.R. Lloyd, J.L. Provis, K.J. Smeaton, J.S.J. van Deventer, Spatial distribution of pores in fly ash-based inorganic polymer gels visualised by Wood's metal intrusion, Microporous Mesoporous Mater. 126 (2009) 32-39, https://doi. org/10.1016/j.micromeso.2009.05.016.

[99] P. Duan, C. Yan, W. Zhou, Influence of partial replacement of fly ash by metakaolin on mechanical properties and microstructure of fly ash geopolymer paste exposed to sulfate attack, Ceram. Int. 42 (2015) 35043517, https://doi.org/10.1016/j.ceramint.2015.10.154

[100] A. Fernandez-Jimenez, I. García-Lodeiro, A. Palomo, Durability of alkaliactivated fly ash cementitious materials, J. Mater. Sci. 42 (2007) 3055-3065, https://doi.org/10.1007/s10853-006-0584-8.

[101] X. Ke, S.A. Bernal, O.H. Hussein, J.L. Provis, Chloride binding and mobility in sodium carbonate-activated slag pastes and mortars, Mater. Struct. 50 (2017) 252, https://doi.org/10.1617/s11527-017-1121-8.

[102] X. Ke, M. Criado, J.L. Provis, S.A. Bernal, Slag-Based Cements That Resist Damage Induced by Carbon Dioxide, ACS Sustain. Chem. Eng. 6 (2018) 50675075, https://doi.org/10.1021/acssuschemeng.7b04730.

[103] X. Ke, S.A. Bernal, J. Provis, Assessing the chloride binding capacity of synthetic cementitious phases in alkali- activated slag simulated pore solution, Ist Int. Conf. Constr. Mater. Sustain. Futur. (2017).

[104] B. Walkley, R.S. Nicolas, S.A. Bernal, J.L. Provis, M. Sani, The role of MgO content in the phase assemblage of alkali-activated synthetic precursors within the system CaO-MgO-Al2O3 -SiO2, 14th Int. Congr. Chem. Cem. (2015). http://www.iccc2015beijing.org/dct/page/1.

[105] B. Walkley, R. San Nicolas, M.A. Sani, J.D. Gehman, J.S.J. van Deventer, J.L. Provis, Synthesis of stoichiometrically controlled reactive aluminosilicate and calcium-aluminosilicate powders, Powder Technol. 297 (2016) 17-33, https://doi.org/10.1016/j.powtec.2016.04.006.

[106] S.A. Bernal, R. San Nicolas, R.J. Myers, R. Mejía De Gutiérrez, F. Puertas, J.S.J Van Deventer, J.L. Provis, MgO content of slag controls phase evolution and structural changes induced by accelerated carbonation in alkali-activated binders, Cem. Concr. Res. 57 (2014) 33-43, https://doi.org/10.1016/j. cemconres.2013.12.003.

[107] P. De Silva, K. Sagoe-Crenstil, V. Sirivivatnanon, Kinetics of geopolymerization: role of $\mathrm{Al} 2 \mathrm{O} 3$ and SiO2, Cem. Concr. Res. 37 (2007) 512-518, https://doi.org/10.1016/j.cemconres.2007.01.003.

[108] X. Ke, S.A. Bernal, J.L. Provis, Controlling the reaction kinetics of sodium carbonate-activated slag cements using calcined layered double hydroxides, Cem. Concr. Res. 81 (2016) 24-37, https://doi.org/10.1016/j. cemconres.2015.11.012.

[109] X. Ke, S.A. Bernal, J.L. Provis, CHLORIDE BINDING CAPACITY OF SYNTHETIC C (A) - S - H TYPE GELS IN ALKALI - ACTIVATED SLAG SIMULATED PORE SOLUTIONS, (n.d.). https://www.researchgate.net/profile/Xinyuan_Ke/ publication/316968948_Assessing_the_chloride_binding_capacity_of_ synthetic_cementitious_phases_in_alkali-activated_slag

simulated_pore_solutions/links/59268cf1aca27295a8f3b7b1/Assessing-thechloride-binding- (accessed May 1, 2018).

[110] X. Ke, S.A. Bernal, J.L. Provis, Uptake of chloride and carbonate by Mg-Al and Ca-Al layered double hydroxides in simulated pore solutions of alkaliactivated slag cement, Cem. Concr. Res. 100 (2017) 1-13, https://doi.org/ 10.1016/j.cemconres.2017.05.015.

[111] M.S.H. Khan, O. Kayali, Chloride binding ability and the onset corrosion threat on alkali-activated GGBFS and binary blend pastes, Eur. J. Environ Civ. Eng. (2016) 1-17, https://doi.org/10.1080/19648189.2016.1230522.

[112] Y. Jun, S. Yoon, J. Oh, A Comparison Study for Chloride-Binding Capacity between Alkali-Activated Fly Ash and Slag in the Use of Seawater, Appl. Sci. 7 (2017) 971, https://doi.org/10.3390/app7100971.

[113] J. Weitkamp, Zeolites and catalysis, Solid State Ionics. 131 (2000) 175-188, https://doi.org/10.1016/S0167-2738(00)00632-9.

[114] E. Ofer-Rozovsky, M. Arbel Haddad, G. Bar Nes, A. Katz, The formation of crystalline phases in metakaolin-based geopolymers in the presence of sodium nitrate, J. Mater. Sci. 51 (2016) 4795-4814, https://doi.org/10.1007/ s10853-016-9767-0.

[115] X. Huang, S. Hu, F. Wang, Y. Liu, Y. Mu, Properties of alkali-activated slag with addition of cation exchange material, Constr. Build. Mater. 146 (2017) $321-$ 328, https://doi.org/10.1016/j.conbuildmat.2017.03.127.

[116] S.A. Walling, S.A. Bernal, L.J. Gardner, H. Kinoshita, J.L. Provis, Phase Formation and Evolution in $\mathrm{Mg}(\mathrm{OH}) 2$-Zeolite Cements, Ind. Eng. Chem. Res. 57 (2018) 2105-2113, https://doi.org/10.1021/acs.iecr.7b04201.

[117] R. Tänzer, Y. Jin, D. Stephan, Alkali activated slag binder: effect of cations from silicate activators, Mater. Struct. Constr. 50 (2017) 91, https://doi.org/ 10.1617/s11527-016-0961-y.

[118] A. Fernández-Jiménez, A. Palomo, M. Criado, Microstructure development of alkali-activated fly ash cement: a descriptive model, Cem. Concr. Res. 35 (2005) 1204-1209, https://doi.org/10.1016/j.cemconres.2004.08.021.

[119] H. Xu, J.S.J. Van Deventer, The geopolymerisation of alumino-silicate minerals, Int. J. Miner. Process. 59 (2000) 247-266, https://doi.org/10.1016/ S0301-7516(99)00074-5.

[120] J.S.J. van Deventer, J.L. Provis, P. Duxson, G.C. Lukey, Reaction mechanisms in the geopolymeric conversion of inorganic waste to useful products, J. Hazard. Mater. 139 (2007) 506-513, https://doi.org/10.1016/j.jhazmat.2006.02.044.

[121] Z. Xie, Y. Xi, Hardening mechanisms of an alkaline-activated class F fly ash, Cem. Concr. Res. 31 (2001) 1245-1249, https://doi.org/10.1016/S0008-8846 (01)00571-3. 
[122] A. Blyth, C.A. Eiben, G.W. Scherer, C.E. White, Impact of activator chemistry on permeability of alkali-activated slags, J. Am. Ceram. Soc. 100 (2017) 48484859, https://doi.org/10.1111/jace.14996.

[123] P. V. Krivenko, H.L. Cao, L.Q. Weng, O.N. Petropavlovskii, High-Performance Alkali-Activated Cement Concretes for Marine Engineering Applications, in: High Perform. Concr. Technol. Appl., InTech, 2016. doi:10.5772/64525.

[124] Z. Zhang, J.L. Provis, H. Wang, F. Bullen, A. Reid, Quantitative kinetic and structural analysis of geopolymers. Part 2. Thermodynamics of sodium silicate activation of metakaolin, Thermochim. Acta. 565 (2013) 163-171, https://doi.org/10.1016/j.tca.2013.01.040.

[125] Z. Sun, A. Vollpracht, Isothermal calorimetry and in-situ XRD study of the $\mathrm{NaOH}$ activated fly ash, metakaolin and slag, Cem. Concr. Res. 103 (2018) 110-122, https://doi.org/10.1016/j.cemconres.2017.10.004.

[126] I. Garcia-Lodeiro, A. Fernandez-Jimenez, A. Palomo, Hydration kinetics in hybrid binders: early reaction stages, Cem. Concr. Compos. 39 (2013) 82-92, https://doi.org/10.1016/j.cemconcomp.2013.03.025.

[127] D.M. Bastidas, A. Fernández-Jiménez, A. Palomo, J.A. González, A study on the passive state stability of steel embedded in activated fly ash mortars, Corros. Sci. 50 (2008) 1058-1065, https://doi.org/10.1016/j.corsci.2007.11.016.

[128] S. Mundra, M. Criado, S.A. Bernal, J.L. Provis, Chloride-induced corrosion of steel rebars in simulated pore solutions of alkali-activated concretes, Cem. Concr. Res. 100 (2017) 385-397, https://doi.org/10.1016/j. cemconres.2017.08.006.

[129] E. Deir, B.S. Gebregziabiher, S. Peethamparan, Influence of starting material on the early age hydration kinetics, microstructure and composition of binding gel in alkali activated binder systems, Cem. Concr. Compos. 48 (2014) 108-117, https://doi.org/10.1016/j.cemconcomp.2013.11.010.

[130] J. Shi, J. Ming, W. Sun, Passivation and chloride-induced corrosion of a duplex alloy steel in alkali-activated slag extract solutions, Constr. Build. Mater. 155 (2017) 992-1002, https://doi.org/10.1016/j.conbuildmat.2017.08.117.

[131] A. Katz, Microscopic study of alkali-activated fly ash, Cem. Concr. Res. 28 (1998) 197-208, https://doi.org/10.1016/S0008-8846(97)00271-8.

[132] K. Yang, C. Yang, B. Magee, S. Nanukuttan, J. Ye, Establishment of a preconditioning regime for air permeability and sorptivity of alkaliactivated slag concrete, Cem. Concr. Compos. 73 (2016) 19-28, https://doi. org/10.1016/j.cemconcomp.2016.06.019.

[133] H.M. Giasuddin, J.G. Sanjayan, P.G. Ranjith, Strength of geopolymer cured in saline water in ambient conditions, Fuel. 107 (2013) 34-39, https://doi.org/ 10.1016/j.fuel.2013.01.035.

[134] M.A.B. Promentilla, T. Sugiyama, T. Hitomi, N. Takeda, Quantification of tortuosity in hardened cement pastes using synchrotron-based X-ray computed microtomography, Cem. Concr. Res. 39 (2009) 548-557, https:// doi.org/10.1016/j.cemconres.2009.03.005.
[135] P.A. Games, H.J. Keselman, J.J. Clinch, Tests for homogeneity of variance in factorial designs, Psychol. Bull. 86 (1979) 978-984, https://doi.org/10.1037/ 0033-2909.86.5.978

[136] K. Kupwade-Patil, E.N. Allouche, P. Eng, Examination of Chloride-Induced Corrosion in Reinforced Geopolymer Concretes, J. Mater. Civ. Eng. 25 (2012) 1465-1476, https://doi.org/10.1061/(ASCE)MT.1943.

[137] I. Ismail, S.A. Bernal, J.L. Provis, S. Hamdan, J.S.J. Van Deventer, Dryinginduced changes in the structure of alkali-activated pastes, J. Mater. Sci. 48 (2013) 3566-3577, https://doi.org/10.1007/s10853-013-7152-9.

[138] S. Caré, Influence of aggregates on chloride diffusion coefficient into mortar, Cem. Concr. Res. 33 (2003) 1021-1028, https://doi.org/10.1016/S0008-8846 (03)00009-7.

[139] W. Li, M. Pour-Ghaz, J. Castro, J. Weiss, Water Absorption and Critical Degree of Saturation Relating to Freeze-Thaw Damage in Concrete Pavement Joints, J. Mater. Civ. Eng. 24 (2012) 299-307, https://doi.org/10.1061/(ASCE)MT.19435533.0000383.

[140] Y. Bu, J. Weiss, The influence of alkali content on the electrical resistivity and transport properties of cementitious materials, Cem. Concr. Compos. 51 (2014) 49-58, https://doi.org/10.1016/j.cemconcomp.2014.02.008.

[141] C. Andrade, Calculation of chloride diffusion coefficients in concrete from ionic migration measurements, Cem. Concr. Res. 23 (1993) 724-742, https:// doi.org/10.1016/0008-8846(93)90023-3.

[142] A. Noushini, Amin Castel, A resistivity-Based Approach to Indicate Chloride Permeability of Geopolymer Concrete, in: Concr. 2015, Researchgate, Melbourne, 2015: p. 10. https://www.researchgatenet/publication/ 280612721_A_Resistivity-Based_Approach_to_Indicate_Chloride_ Permeability of Geopolymer_Concrete.

[143] D. Ravikumar, N. Neithalath, An electrical impedance investigation into the chloride ion transport resistance of alkali silicate powder activated slag concretes, Cem. Concr. Compos. 44 (2013) 58-68, https://doi.org/10.1016/j. cemconcomp.2013.06.002.

[144] W. Jason Weiss, R.P. Spragg, O. Burkan Isgor, M. Tyler Ley, T. Van Dam, Toward performance specifications for concrete: Linking resistivity, RCPT and diffusion predictions using the formation factor for use in specifications, in: High Tech Concr. Where Technol. Eng. Meet - Proc. 2017 Fib Symp., Springer International Publishing, Cham, 2017: pp. 2057-2065. doi:10.1007/978-3319-59471-2_235.

[145] M. Criado, S.A. Bernal, P. Garcia-Triñanes, J.L. Provis, Influence of slag composition on the stability of steel in alkali-activated cementitious materials, J. Mater. Sci. 53 (2018) 5016-5035, https://doi.org/10.1007/ s10853-017-1919-3.

[146] P. Duxson, A. Fernández-Jiménez, J.L. Provis, G.C. Lukey, A. Palomo, J.S.J. Van Deventer, Geopolymer technology: the current state of the art, J. Mater. Sci. 42 (2007) 2917-2933, https://doi.org/10.1007/s10853-006-0637-z.
1510

1511

1512

1513

1514

1515

1516

1517

1518

1519

1520

1521

1522

1523

1524

1525

1526

1527

1528

1529

1530

1531

1532

1533

1534

1535

1536

1537

1538

1539

1540

1541

1542

1543

1544

1545

1546

1547

1548

1549 